\title{
Carbonate petrography as an indicator of climate and sea-level changes: new data from Bahamian Quaternary units
}

\author{
PASCAL KINDLER* and PAUL J. HEARTY† \\ *Department of Geology and Palaeontology, University of Geneva, Maraîchers 13, \\ 1211 Geneva 4, Switzerland \\ †Chertsey \#112, PO Box N-337, Nassau, The Bahamas
}

\begin{abstract}
Coeval stratigraphic units of similar petrology occur throughout the northern Bahamas islands. The petrographic composition of these limestones provides clues about regional sea level and climate changes during the late Quaternary. At least eight fossil shoreline units, which are linked to transgressive episodes between the middle Pleistocene and the late Holocene, are recognized in the Bahamas. The petrographic composition of these units is either dominated by ooids and peloids or by bioclasts. Sedimentol ogical observations demonstrate that oolitic-peloidal units were formed when sea level was higher than today, whereas skeletal units were deposited at or bel ow modern ordnance datum. Skeletal units may reflect times of partial, or modest platform flooding, when the bulk of sediments brought to islands originates from bank-margin reefs. In contrast, oolitic-pel oidal units correspond to major flooding events and active water circulation on the bank top. Cement fabrics further show that the early diagenesis of oolitic units took place during warm and humid climatic conditions, whereas skeletal rock bodies underwent subaerial diagenesis during drier climatic conditions characterized by marked seasonal changes. This example from the Bahamas suggests that compositional analysis of limestone from fossil carbonate platforms could be used for resolving ancient climate and sea-level changes.
\end{abstract}

\section{INTRODUCTION}

Geological research in the Bahamas archipelago traditionally focused on modern sediments and sedimentation processes (e.g. Illing, 1954; Purdy, 1963; Ball, 1967; Hine, 1977; Hine et al., 1981) and platform architecture (e.g. Eberli \& Ginsburg, 1989). Only recently have geologists begun to resolve the stratigraphy of individual islands (Garrett \& Gould, 1984; Carew \& Mylroie, 1985; Hearty \& Kindler, 1993a; Kindler, 1995; Kindler \& Hearty, 1995). Petrographic studies of Bahamian limestones are still sparse and, in most cases, report on diagenetic textures and processes (Friedman, 1964; Robinson, 1967; Harris, 1979; Gardner \& McLaren, 1993; McLaren, 1993). Many of these studies (e.g. Garrett \& Gould, 1984; Hutto $\&$ Carew, 1984) concluded that limestone composition only reflects local morphological controls and cannot be used as a tool for correlating stratigraphic units within and between islands.

Contrasting with previous studies, this paper shows that coeval stratigraphic units of similar petrol ogy occur throughout the northern Bahamas islands. The petrographic composition of these limestones, which may be dominated either by ooids or by bioclasts, further provides important information about regional sea-level and climate changes during the late Quaternary.

\section{GEOLOGICAL SETTING}

The Bahamas islands (Fig. 1) represent the emerged portion of a series of isolated flat-topped carbonate platforms located to the east of Florida and to the north of Cuba, extending for more than $1200 \mathrm{~km}$ in a N-S direction and $500 \mathrm{~km}$ in an 


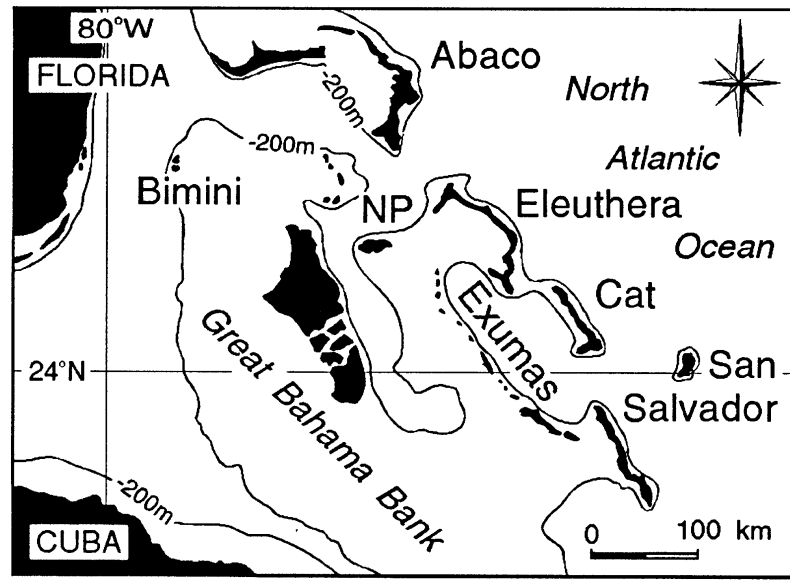

Fig. 1. Location map of the study area.

$\mathrm{E}-\mathrm{W}$ direction. We focused our research on the north-western Bahamas (the islands of Abaco, Bimini, New Providence, Eleuthera, Cat, San Salvador and the Exuma chain), which are considered to be tectonically stable or undergoing slight subsidence $\left(1.6 \mathrm{~cm} 10^{3} \mathrm{yr}^{-1}\right.$ according to Lynts, 1970, and Mullins \& Lynts, 1977).

According to many previous authors (e.g. Newell \& Rigby, 1957; Bathurst, 1975; Beach \& Ginsburg, 1980), the Bahamas isl ands mai nly consist of oolitic limestone formed during the last interglacial period (Sangamonian). Only recently did Garrett \& Gould (1984) recognize several distinct depositional phases on New Providence Island, including three subphases pre-dating the Sangamonian. On the basis of earlier work on San Sal vador (Carew \& Mylroie, 1985, 1987; Stowers et al., 1989), Carew \& Mylroie (1991) proposed a tripartite stratigraphy for the Bahamas comprising a Holocene unit (Rice Bay Formation), a Sangamonian unit (Grotto Beach Formation) and a pre-Sangamonian unit (Owl's Hole Formation).
This stratigraphic succession was thoroughly revised and completed by Hearty \& Kindler (1993a,b, 1994). It now includes eight lithostratigraphic units extending from the middle Pleistocene to the late Holocene (Table 1 ). These units were formed in terrestrial and marine environments and are bounded by pal aeosols that are not considered in this study.

\section{METHODS}

This study relied on a multi-method approach combining morphostratigraphy, geomorphology, sedimentology, petrography, and radiometric and amino-acid racemization dating. This approach is detailed in previous papers (Hearty \& Kindler, 1993a, 1994; Kindler, 1995) and will only be briefly summarized below.

We first evaluated the morphostratigraphy with topographic maps and air photographs applying the principles of lateral accretion (Itzhaki, 1961; Vacher, 1973) and catenary growth (Garrett \& Gould, 1984). The former states that, on a prograding shoreline, deposits become younger seaward. In contrast, the latter principle asserts that catenary ridges are younger than their anchoring headlands (Fig. 2). Measured sections were established at 61 critical sites (Fig. 3). Physical and biogenic sedimentary structures were examined in the field to obtain information about depositional settings and sea-level elevation during formation of the different rock units. Following petrographic examination in the field, over 500 samples were collected from the measured sections and from some 150 additional locations. Two hundred and fifty selected samples were impregnated with blue epoxy resin, thinsectioned and examined under a polarizing

Table 1. Nomenclature of Bahamian stratigraphic units.

\begin{tabular}{|c|c|c|c|c|c|}
\hline Epoch & $\begin{array}{l}\text { Isotope } \\
\text { stage }\end{array}$ & $\begin{array}{c}\text { San Salvador } \\
\text { Carew \& Mylroie } \\
\text { (1985) }\end{array}$ & $\begin{array}{c}\text { San Salvador } \\
\text { Hearty \& Kindler } \\
\text { (1993a) }\end{array}$ & $\begin{array}{l}\text { The Bahamas } \\
\text { Hearty \& Kindler } \\
\text { (1993b) }\end{array}$ & $\begin{array}{l}\text { This } \\
\text { study }\end{array}$ \\
\hline Holocene & $\begin{array}{l}1 \\
1\end{array}$ & $\begin{array}{l}\text { Hanna Bay Member } \\
\text { North Point Member }\end{array}$ & $\begin{array}{l}\text { Hanna Bay Member } \\
\text { North Point Member }\end{array}$ & $\begin{array}{l}\text { complex VIIb } \\
\text { complex VIIa }\end{array}$ & $\begin{array}{l}\text { unit VIII } \\
\text { unit VII }\end{array}$ \\
\hline Late Pleistocene & $\begin{array}{l}5 a \\
5 e \\
5 e \\
5 e\end{array}$ & $\begin{array}{l}\text { unrecognized } \\
\text { unrecognized } \\
\text { Cockburn Town Member } \\
\text { French Bay Member }\end{array}$ & $\begin{array}{l}\text { Almgreen Cay Formation } \\
\text { Fernandez Bay Member } \\
\text { Cockburn Town Member } \\
\text { French Bay Member }\end{array}$ & $\begin{array}{l}\text { complex VIc } \\
\text { complex VIb } \\
\text { complex VIa }\end{array}$ & $\begin{array}{l}\text { unit VI } \\
\text { unit V } \\
\text { unit IV }\end{array}$ \\
\hline Middle Pleistocene & $\begin{array}{l}7 \\
7 \\
? 9\end{array}$ & $\begin{array}{l}\text { unrecognized } \\
\text { Owl's Hole Formation } \\
\text { unrecognized }\end{array}$ & $\begin{array}{l}\text { Fortune Hill Formation } \\
\text { Owl's Hole Formation } \\
\text { unrecognized }\end{array}$ & $\begin{array}{l}\text { complex Vb } \\
\text { complex Va } \\
\text { complex IV }\end{array}$ & $\begin{array}{l}\text { unit III } \\
\text { unit II } \\
\text { unit I }\end{array}$ \\
\hline
\end{tabular}


Fig. 2. Sketch illustrating the basic principles of morphostratigraphy used in this study.

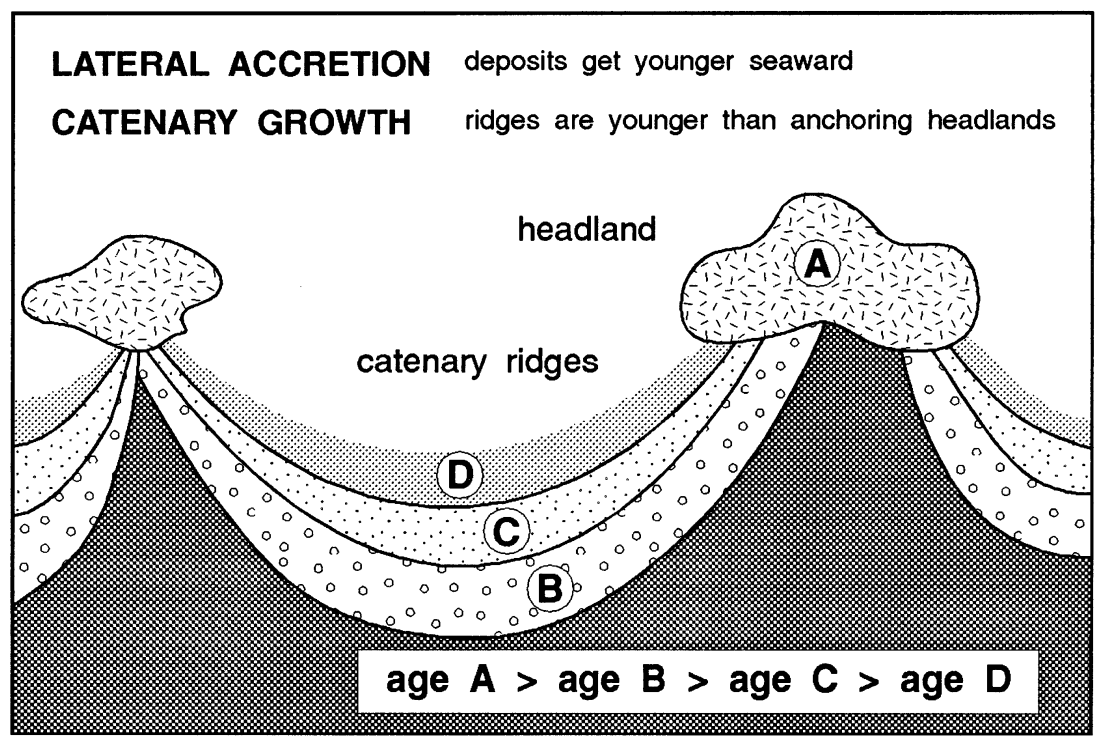

microscope. Carbonate minerals were identified by staining techniques (Friedman, 1959; Miller, 1988). Quantitative analysis was made with a SWIFT automatic point-counter (model F), according to the method developed by Chayes (1956) and later revised by Halley (1978), Harrel (1981) and Flügel (1982). A minimum of two 250-point counts were performed on separate portions of each thin-section to reduce errors linked to rock heterogeneity. We first calculated the percentages of grains, cement and primary porosity. Among the grains, we tabulated pel oids, normal and superficial ooids, lithoclasts, aggregates and several types of bioclasts (al gae, coral and mollusc fragments, benthonic foraminifers). Pel oids include faecal pellets and rounded, structurel ess micritic grains. Micritized bioclastic particles, identified by distinctive shape or partly preserved texture, were counted as bioclasts. Standard deviation varies between 1 and $5 \%$ depending on particlefrequency. For comparative purposes, we established a 'skel etal ratio' for each sample by dividing the percentage of bi oclasts by the total percentage of ooids, peloids and bioclasts. Tables 3-9 provide a synthesis of our results for each rock unit; more details of the grain counts are available upon request.

Whole-rock ${ }^{14} \mathrm{C}$-dating analyses were performed on a few Holocene samples, whereas uranium-series dating of unal tered corals carried out by other authors (e.g. Chen et al., 1991) provided 'golden spikes' in the Pleistocene. A mino-acid racemization (AAR) dating was used on whole-rock samples for correlating units within and between islands, and determining their relative ages. The method relies on the slow interconversion (racemization) of L-amino acids, within indigenous proteins preserved in the sample, to increasing proportions of their respective D-configurations until an equilibrium mixture of $\mathrm{D}$ - and L-amino acids is attained. This study utilized the ratio of stereoisomers of isoleucine (D-alloisoleucine/L-isoleucine or A/I ratio). $A / I$ ratio is zero in most living tissues (D-alloisoleucine is not present), and approaches an equilibrium ratio of 1.3 at an exponentially decreasing rate with increasing time since death of the organism. In numerous previous studies (e.g. Wehmiller, 1983; Hearty et al., 1986; Miller \& Brigham-Grette, 1989), A/l ratios are measured from commonly occurring terrestrial and marine mollusc shells, but the method has also been successfully applied to whole-rock limestone samples (Hearty et al., 1992; Hearty \& Kindler, 1993a, 1994). The AAR results are summarized in Table 2; however, because this study focuses on petrography, the AAR data will be reported in greater detail in a subsequent paper.

\section{STRATIGRAPHY OF THE BAHAMIAN ISLANDS}

\section{Unit I - middle Pleistocene oolites (? isotope stage 9)}

Friedman (1964) had previously noticed 'tracts of altered oolitic limestone' in the central part of New Providence, contrasting with betterpreserved Pleistocene oolite elsewhere on the 


\begin{tabular}{|c|c|c|}
\hline (3) (1) (1) & \multicolumn{2}{|c|}{$\begin{array}{l}\text { STUDIED SITES } \\
\text { 1: Gun Cay (south) } \\
\text { 2: Gun Cay (north) } \\
\text { 3: Alice Town } \\
\text { 4: Paradise Point }\end{array}$} \\
\hline $24.30 \mathrm{~V}$ & $\begin{array}{l}\text { 5: Bain Town } \\
\text { 6: McQueens } \\
\text { 7: Fernandez Bay } \\
\text { 8: Arthur's Town airport }\end{array}$ & $\begin{array}{l}\text { 9: Mt Alvernia } \\
\text { 10: Greenwood Bay } \\
\text { 11: Columbus Point }\end{array}$ \\
\hline (12) & \multicolumn{2}{|c|}{$\begin{array}{l}\text { 12: Dune Pass Bay } \\
\text { 13: Caribbean Marine Resarch Center } \\
\text { 14: Beach Cottage } \\
\text { 15: Long Beach } \\
\text { 16: Lee Stocking SE end } \\
\text { 17: Stocking Island }\end{array}$} \\
\hline (18) & $\begin{array}{l}\text { 18: Clifton Pier } \\
\text { 19: Goulding Cay } \\
\text { 20: Lyford Cay } \\
\text { 21: Gambier Ridge } \\
\text { 22: Delaport Point } \\
\text { 23: Blue Hill Ridge }\end{array}$ & $\begin{array}{l}\text { 24: Hunt's Cave Quarry } \\
\text { 25: East Street Cut } \\
\text { 26: Nassau Ridge } \\
\text { 27: Paradise Island } \\
\text { 28: Salt Cay } \\
\text { 29: St Augustine Quarry }\end{array}$ \\
\hline SALVADOR (34) (30) (39) & $\begin{array}{l}\text { 30: North Point } \\
\text { 31: Man Head Cay } \\
\text { 32: Dixon Hill } \\
\text { 33: Almgreen Cay } \\
\text { 34: The Bluff } \\
\text { 35: Dance Hall Cave }\end{array}$ & $\begin{array}{l}\text { 36: The Gulf } \\
\text { 37: Sandy Point } \\
\text { 38: Grotto Beach } \\
\text { 39: Watling's Quarry } \\
\text { 40: Cockburn Town area } \\
\text { 41: Observation Tower Rd. }\end{array}$ \\
\hline (42) (43) (45) (46) (46) & $\begin{array}{l}\text { 42: Crown Haven } \\
\text { 43: Angel Fish Point } \\
\text { 44: Conch Rock Creek } \\
\text { 45: Fire Road Village } \\
\text { 46: Green Turtle Cay }\end{array}$ & $\begin{array}{l}\text { 47: Split Rock } \\
\text { 48: Treasure Cay } \\
\text { 49: Hope Town } \\
\text { 50: Wilson City } \\
\text { 51: Hole in The Wall }\end{array}$ \\
\hline ELEUTHERA (52) (54) & $\begin{array}{l}\text { 52: The Bluff } \\
\text { 53: Harbour Island } \\
\text { 54: Boiling Hole } \\
\text { 55: The Cliffs } \\
\text { 56: North Palmetto Point }\end{array}$ & $\begin{array}{l}\text { 57: Savannah Sound } \\
\text { 58: East End Point } \\
\text { 59: Alice Town } \\
\text { 60: Gregory Town } \\
\text { 61: Glass Window }\end{array}$ \\
\hline
\end{tabular}

Fig. 3. Index maps of studied sites.

island. However, he did not recognize these 'tracts' as a separate stratigraphic unit. Unit I usually occurs in the interior of islands and at the base of rapidly eroding cliffs al ong the Atlantic shorelines. A part from New Providence, we have recognized this unit on cliff exposures in Abaco, Cat and Eleuthera, and in the centre of San Sal vador (Sites 6, 35, 41, 47, 50, 51, 54, 61, Fig. 3).

Sedimentary structures commonly observed within Unit I are steep $\left(>30^{\circ}\right)$, landward-dipping foresets indicative of an aeolian setting and fenestrae-rich planar cross-beds typical of foreshore sedimentation. At Hunt's Cave Quarry (Site 24, Figs 3 and 4), low-angle cross-bedding, shell hash and fenestrae occur at an elevation of $+7 \mathrm{~m}$, suggesting that sea level was higher than present (about $+6 \mathrm{~m}$ ) during deposition. Ooids and peloids make up over $70 \%$ of the constituent grains of this unit (Table 3). Ooids, which usually outnumber peloids, display rather thick cortices that may still retain their original aragonite mineralogy and tangential microstructure. However, in many cases, leaching and calcitization of cortices resulted in the formation of oomoulds, fallen nuclei and 'in-situ calcitized ooids' (Richter, 1983; Fig. 5), the latter being less common within Sangamonian and Holocene oolites. The high proportion of peloids in most samples collected from El euthera (Table 3) suggests some local morphological control on petrographic composition or a slightly different age for these samples. Bioclasts are represented by mollusc, algal and coral fragments which seldom exceed $20 \%$ of the constituent grains. Unit I is further characterized by a large proportion (over $25 \%$, Table 3) of Iow-magnesium calcite (LMC) cement 
Table 2. Mean wholerock A/I ratios and number of analysed samples (in parentheses) from the islands of Abaco (ABI), New Providence (NPI), Eleuthera (ELU), Cat (CAT), San Salvador (SSI) and the Exuma chain (EXU). Unit designations correspond with those used in Table 1. All data reported in this table were obtained from Dr Darrell Kaufmann (Utah State University). Statistical data are available upon request from Dr P. J. Hearty.

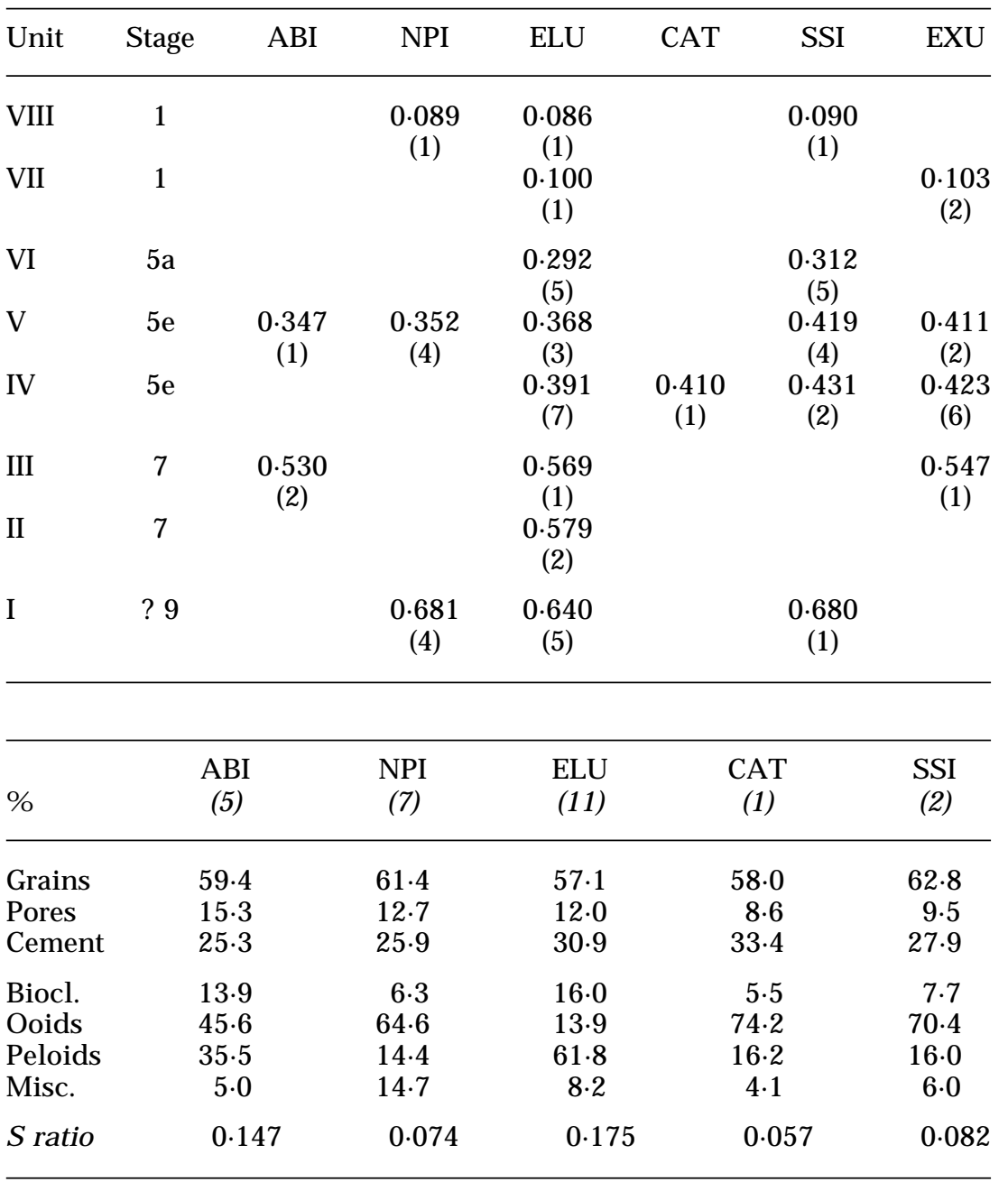

Table 3. Petrographic characteristics of Unit I (? isotope stage 9 ool ite). This unit was found on the islands of A baco (ABI), New Providence (NPI), Eleuthera (ELU), Cat (CAT) and San Salvador (SSI). It has so far not been identified in the Bimini islands or in the Exuma chain. In parentheses, the number of analysed samples per island. Skeletal ratio (S ratio) is obtained by dividing the percentage of bioclasts by the total percentage of bioclasts, peloids and ooids. typical of the meteoric environment (Longman, 1980). Cement textures include isopachous rims of anhedral crystals, menisci, blocky fillings and large $(>1 \mathrm{~mm}$ ) subhedral crystals enclosing adjacent grains. One sample collected at $+5 \mathrm{~m}$ in northern Eleuthera (Site 61, Fig. 3) clearly shows two generations of cement (Fig. 6): (1) early LMC equant spar occurring at grain contacts and locally infilling pore spaces, and (2) late isopachous rims of fibrous aragonite. The former cement precipitated in a freshwater, possibly vadose setting, whereas the latter was formed in a marine phreatic environment (Longman, 1980).

The age of Unit I is demonstrated by (1) its stratigraphic position in the central part of islands or at the base of vertical successions; (2) its occurrence below deep-red, mature palaeosols and thick calcrete crusts; (3) a substantial degree of diagenetic alteration; (4) the local occurrence of a second generation of marine cement indicating submergence by a younger, possibly
Sangamonian (Hearty \& Kindler, 1995) flooding event that reached higher than modern sea level; and (5) el evated $A / I$ ratios (Table 2 ). The high $(+6 \mathrm{~m})$ pal aeo sea-level datum inferred from these limestones suggests that the oxygen isotope composition of coeval oceanic waters was close to Sangamonian values. Comparison with the isotopic record from deep-sea sediments indicates that deposition of this unit could have occurred during isotope stage 9 (see Fig. 20).

\section{Units II and III - middle Pleistocene bioclastic calcarenites (isotope stage 7)}

Garrett \& Gould (1984) and Carew \& Mylroie (1985) mentioned earlier pre-Sangamonian bioclastic calcarenites on New Providence and San Salvador, respectively. Recently, Hearty \& Kindler (1993a) and Kindler \& Hearty (1995) showed that these deposits are far more extensive than previously thought. In particular, they form 


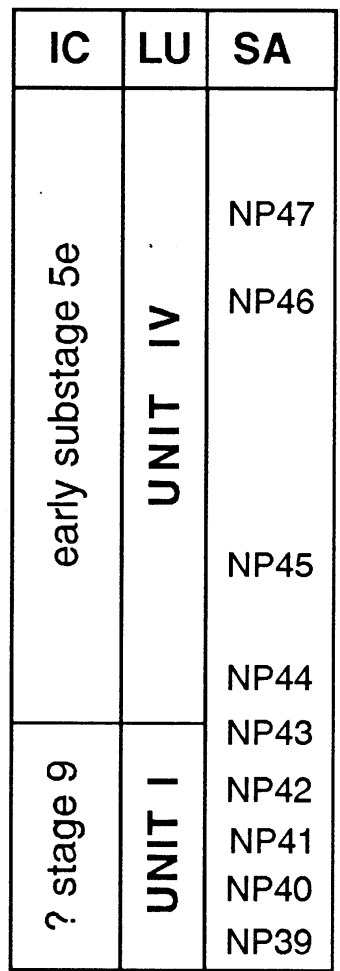

Q7 eolian foresets $\square$ eolian topsets $\because$ beach bedding \& fenestrae

Fig. 4. Hunt's Cave Quarry section (New Providence Island, Site 24, Fig. 3) showing the superposition of Units I and IV. IC=isotope chronology; LU= lithostratigraphic unit; $\mathrm{SA}=$ sample number.

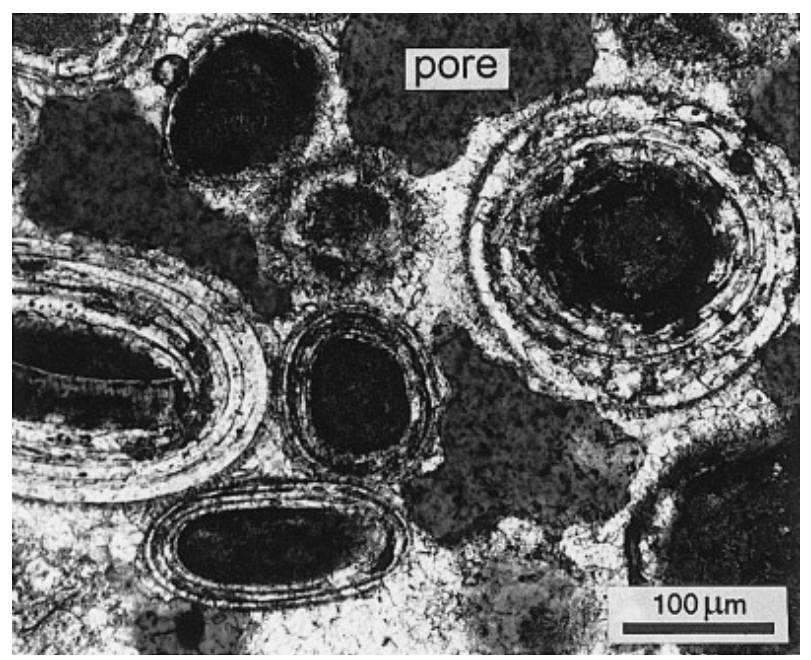

Fig. 5. Sample NP 41, Unit I, Hunt's Cave Quarry, New Providence. In situ cal citized ooids. Ooid cortices have been calcitized, but peloidal nuclei still retain their aragonitic mineralogy and have stained black when covered with Fiegl's solution. In situ calcitized ooids frequently occur in Unit I deposits, but are less common in younger oolites.

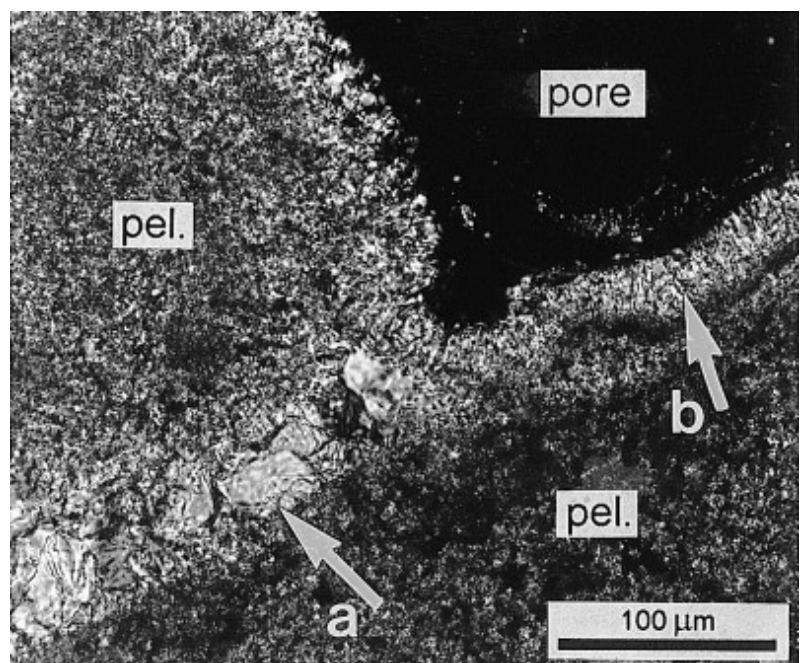

Fig. 6. Sample EL 92, Unit I, Glass Window (Eleuthera, Site 61, Fig. 3). A second generation of fibrous aragonite cement (arrow b) overlies an early low-Mg calcite cement (arrow a) linking two pel oids (pel.). The former calcitic cement precipitated in a freshwater vadose setting, whereas the latter aragonitic fibres formed in a marine phreatic setting during a younger phase of platform flooding.

impressive sea cliffs al ong the ocean-facing shoreline of Abaco, Eleuthera and Cat (Sites 5, 11, 43, $51,54,55,61$, Fig. 3), and probably occur also in the Exumas (Site 12, Fig. 3; Kindler, 1995). Two stratigraphic units of similar petrographic composition can be recognized among these deposits. In San Salvador, the Fortune Hill Formation (Hearty \& Kindler, 1993a; Unit III) includes the rocks of Dixon and Fortune Hills (Site 32, Fig. 3), whereas the Owl's Hole Formation (Carew \& Mylroie, 1985; Unit II) is exposed at Grotto Beach and in Watling's Quarry (Sites 38, 39, Fig. 3). In Cat and Eleuthera (Sites 11, 55, 61, Figs 3 and 7), both units appear in vertical succession and are separated by a brecciated red palaeosol containing black pebbles and calcrete horizons. On New Providence (Site 23, Fig. 3), two pre-Sangamonian units clearly occur in distinct morphostratigraphic positions (fig. 5 in Garrett \& Gould, 1984).

Units II and III were deposited in a subaerial environment as shown by steep aeolian foresets (Fig. 7) and low-amplitude wind-ripples (fig. 8b in Kindler \& Hearty, 1995). Occurrence of these sedimentary structures below modern ordnance datum indicates that deposition took place when sea level was lower than today. Bioclasts, which can either be leached or wholly micritized (Fig. $8)$, usually represent over $60 \%$ of the constituent grains (Table 4). They essentially derive from the breaking of marine organisms typically found in 
Fig. 7. The Cliffs section (Eleuthera, Site 55, Fig. 3). Cliff section showing the vertical succession of Units II and III. Both units consist of bioclastic aeolianites pre-dating the Sangamonian interglacial period (Kindler \& Hearty, 1995). A palaeosol including breccia pockets and calcrete horizons separates both units. Large arrow points to steep aeolian foresets dipping below sea level at the base of Unit II. Cliff height is $15 \mathrm{~m}$.

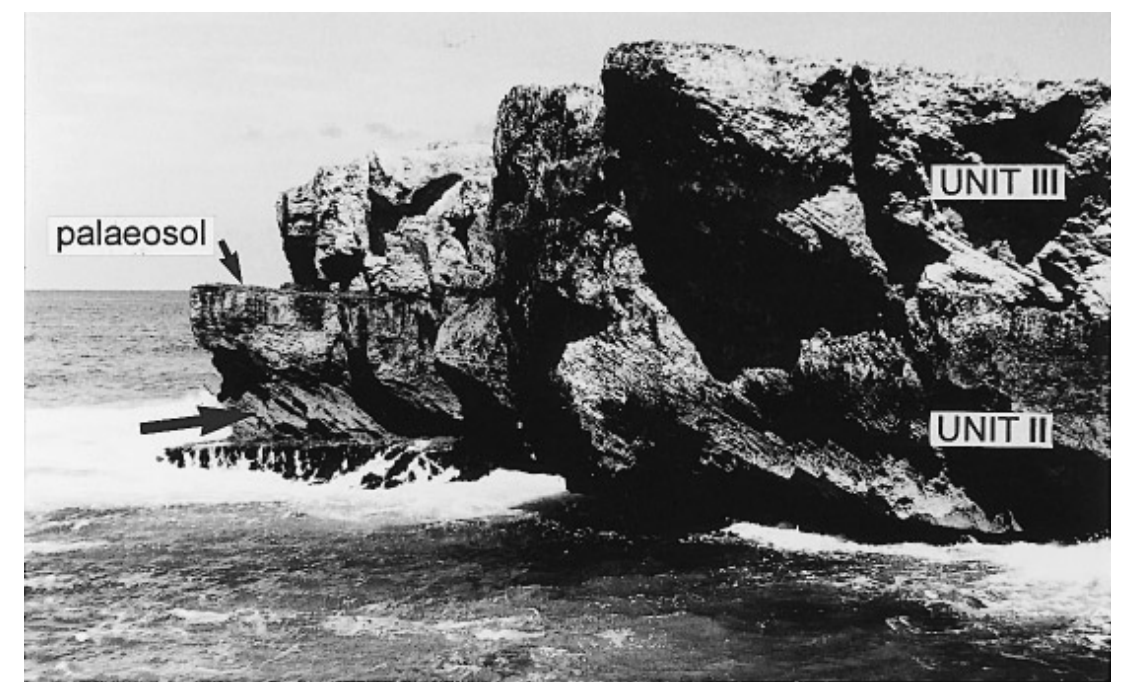

reefs and windward lagoons in the Bahamas (coral and red al gae debris, benthic foraminifers; Newell \& Rigby, 1957). Ooid content averages around 4\% (Table 4). Grains are usually cemented by finely crystallized LMC spar that either concentrates at grain contacts or forms nonisopachous rims ('grain-skin' cement; Land et al., 1967; Ward, 1975; Fig. 9). Syntaxial cement overgrowth also occurs around echinoid fragments. These cementation fabrics indicate a freshwater vadose diagenetic environment (Longman, 1980; McLaren, 1993). A second generation of marine vadose cement has been observed within one

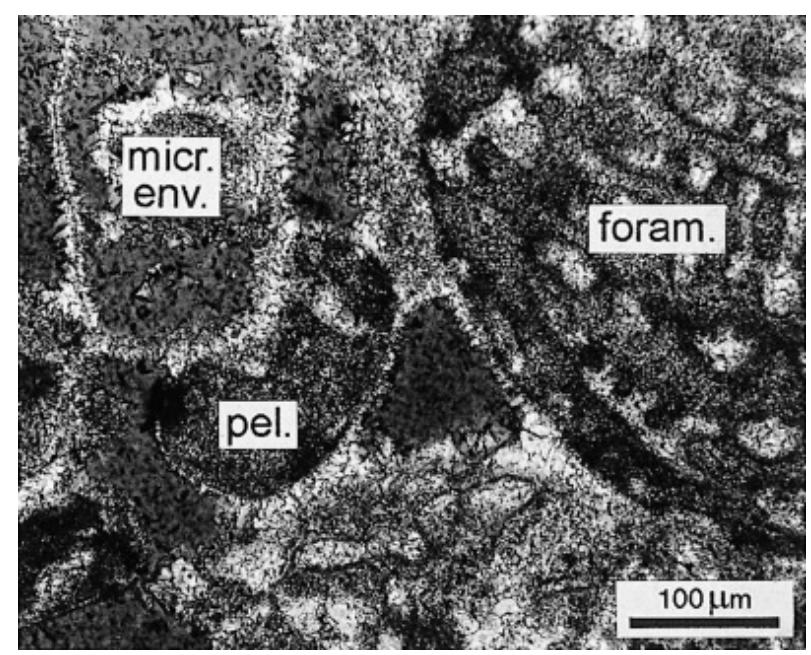

Fig. 8. Sample EL 76, Unit II, The Cliffs, Eleuthera. Microfacies of middle Pleistocene bioclastic calcarenites; note recrystallized foraminifer fragment (foram.) and empty micrite envelope (micr. env.); pel.=peloid. Leaching and recrystallization of particles characterize Units II and III, but are less common in younger bioclastic limestones (Units VI and VIII). sample collected at $11 \mathrm{~m}$ above mean sea level from a coastal cliff in Eleuthera. The patchy distribution of this cement and the elevation at which it occurs suggest that it could be related to modern sea spray.

The ages of Units II and III have been locally estimated at about 200-300 ka on the basis of high A/I ratios (Table 2; Hearty \& Kindler, 1993a). These ages are supported by the morphostratigraphic and stratigraphic position of the units between middle Pleistocene and Sangamonian oolites (Fig. 10), and possibly by their advanced stage of diagenetic alteration at all scales. Recognition of a lower than present sea level during formation of these calcarenites and comparison with the oxygen-isotope record from deep-sea sediments suggest that they could represent separate depositional events during isotope stage

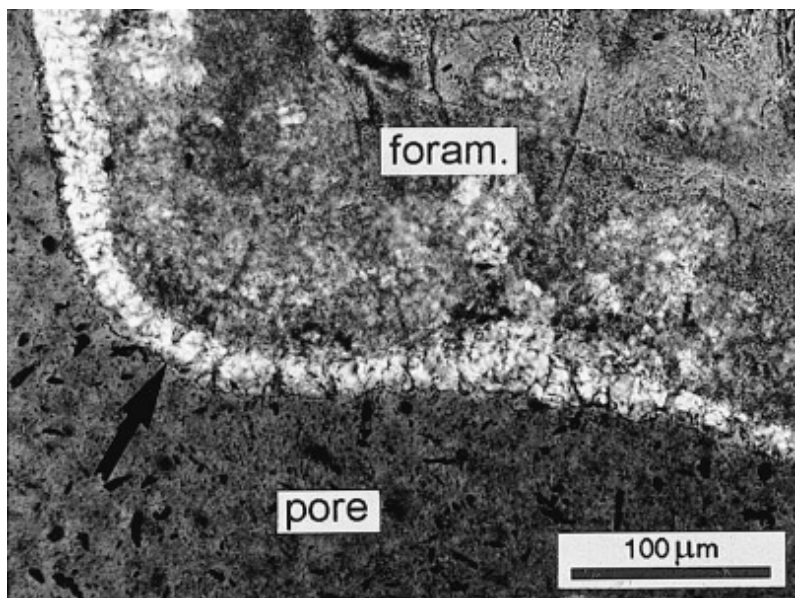

Fig. 9. Sample EL 76, Unit II, The Cliffs, Eleuthera. 'Grain-skin' cement (arrow) rimming foraminifer fragment (foram.). Note small crystal size. 


\begin{tabular}{|c|c|c|c|c|c|c|}
\hline$\%$ & $\begin{array}{c}A B I \\
(5)\end{array}$ & $\begin{array}{l}\text { NPI } \\
\text { (8) }\end{array}$ & $\begin{array}{l}\text { ELU } \\
\text { (15) }\end{array}$ & $\begin{array}{c}\text { CAT } \\
\text { (3) }\end{array}$ & $\begin{array}{l}\text { SSI } \\
\text { (13) }\end{array}$ & $\begin{array}{c}\text { EXU } \\
\text { (2) }\end{array}$ \\
\hline $\begin{array}{l}\text { Grains } \\
\text { Pores } \\
\text { Cement }\end{array}$ & $\begin{array}{l}57 \cdot 9 \\
24 \cdot 2 \\
17 \cdot 9\end{array}$ & $\begin{array}{l}59 \cdot 6 \\
22 \cdot 4 \\
18 \cdot 0\end{array}$ & $\begin{array}{l}58.0 \\
29.5 \\
12.5\end{array}$ & $\begin{array}{r}61 \cdot 9 \\
29 \cdot 1 \\
9 \cdot 0\end{array}$ & $\begin{array}{l}58 \cdot 5 \\
30 \cdot 1 \\
11 \cdot 4\end{array}$ & $\begin{array}{r}56 \cdot 5 \\
40 \cdot 6 \\
2 \cdot 9\end{array}$ \\
\hline $\begin{array}{l}\text { Biocl. } \\
\text { Ooids } \\
\text { Peloids } \\
\text { Misc. }\end{array}$ & $\begin{array}{r}75 \cdot 5 \\
5 \cdot 6 \\
15 \cdot 0 \\
4.0\end{array}$ & $\begin{array}{r}59 \cdot 4 \\
9 \cdot 0 \\
22 \cdot 5 \\
9 \cdot 1\end{array}$ & $\begin{array}{r}86 \cdot 6 \\
2 \cdot 8 \\
7 \cdot 0 \\
3 \cdot 6\end{array}$ & $\begin{array}{r}84 \cdot 7 \\
1 \cdot 2 \\
11 \cdot 8 \\
2 \cdot 4\end{array}$ & $\begin{array}{r}75 \cdot 6 \\
0.7 \\
18.9 \\
4.7\end{array}$ & $\begin{array}{r}88 \cdot 4 \\
2 \cdot 7 \\
7 \cdot 1 \\
1.7\end{array}$ \\
\hline S ratio & 0.786 & 0.654 & 0.898 & 0.867 & 0.794 & 0.901 \\
\hline
\end{tabular}

Table 4. Petrographic

characteristics of Units II and III (isotope stage 7 bioclastic cal carenites). A bbreviations are the same as for Table 3. Note the high percentages of cement compared to younger bioclastic units (Tables 7 and 9).

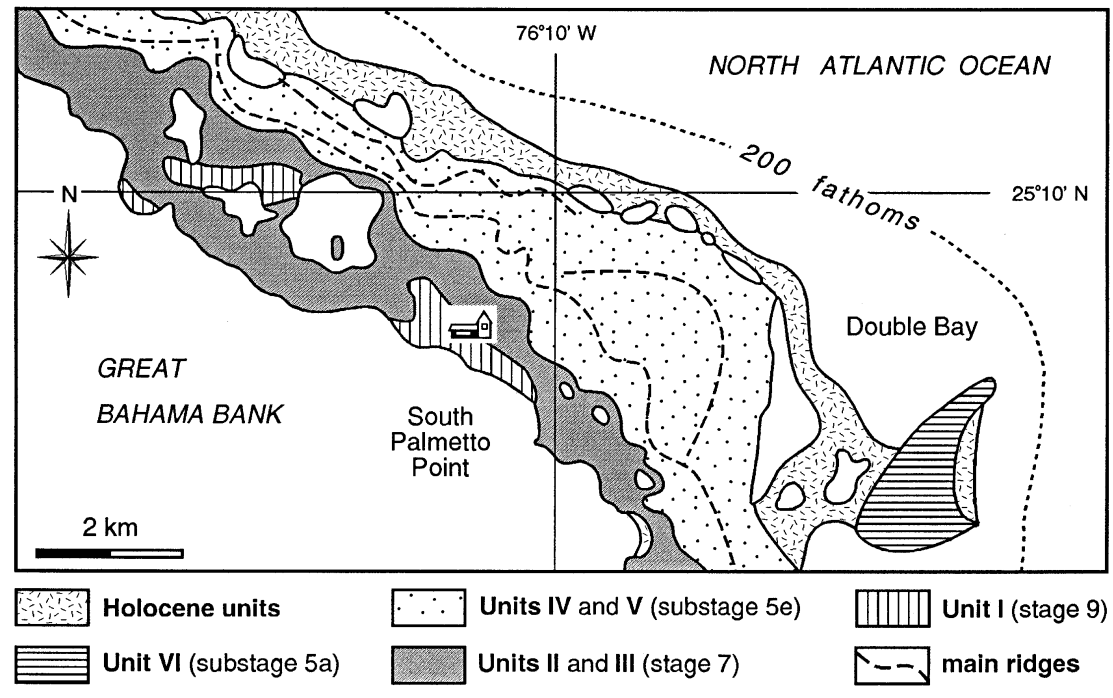

Fig. 10. Geological map of the Palmetto Point area in central El euthera. Stage 7 bioclastic cal carenites (including Units II and III) occur between stage 9 (Unit I) and substage 5e (Units IV and V) oolites. Note that Pleistocene units become younger seaward.
7 (see Fig. 20). Pre-Sangamonian bioclastic calcarenites can be distinguished from younger skeletal counterparts (Units VI and VIII) by the frequent occurrence of grain recrystallization and leaching, and a higher percentage of cement.

\section{Unit IV and V - early Sangamonian oolites (isotope substage 5e)}

On San Sal vador Isl and, early Sangamonian (substage 5e) deposits comprise the Grotto Beach Formation (Carew \& Mylroie, 1985; Hearty \& Kindler, 1993a) and include three distinctive lithostratigraphic units: (1) the French Bay Member (Carew \& Mylroie, 1985), (2) the Cockburn Town Member (Carew \& Mylroie, 1985) and (3) the Fernandez Bay Member (Hearty \& Kindler, 1993a). The French Bay and the Fernandez Bay Members are former oolitic coastal deposits, whereas the Cockburn Town Member represents a reef facies that has been precisely dated at 131119 ka (Chen et al., 1991). Substage 5e oolites occur throughout the Bahamas. They form the highest el evation of the archipelago $(63 \mathrm{~m}$, Mt Alvernia on Cat, Site 9, Fig. 3) and virtually blanket Grand Bahama (Gerhardt, 1983), San Salvador and Abaco Islands. The conspicuous nature of these units perhaps led to the common misconception that rock exposures in the Bahamas only consist of late Pleistocene oolite (e.g. Newell \& Rigby, 1957; Bathurst, 1975; Beach $\&$ Ginsburg, 1980).

The early Sangamonian oolites display shallowing-upward sequences from subtidal to aeolian facies. Shoreface and beach deposits can be observed up to an elevation of $7 \mathrm{~m}$. Elevated subtidal deposits, showing small-scale trough cross-stratification, herring-bone structures and callianassid burrows, are best exposed at Clifton Pier (New Providence, Site 18, Fig. 3; fig. 7 in Aurell et al., 1995), Sandy Point (San Salvador, Site 37, Fig. 3) and Boiling Hole (Eleuthera, Site 54, Fig. 3; Kindler \& Hearty, 1995). In addition to steep foresets and rhizoliths, aeolian deposits 


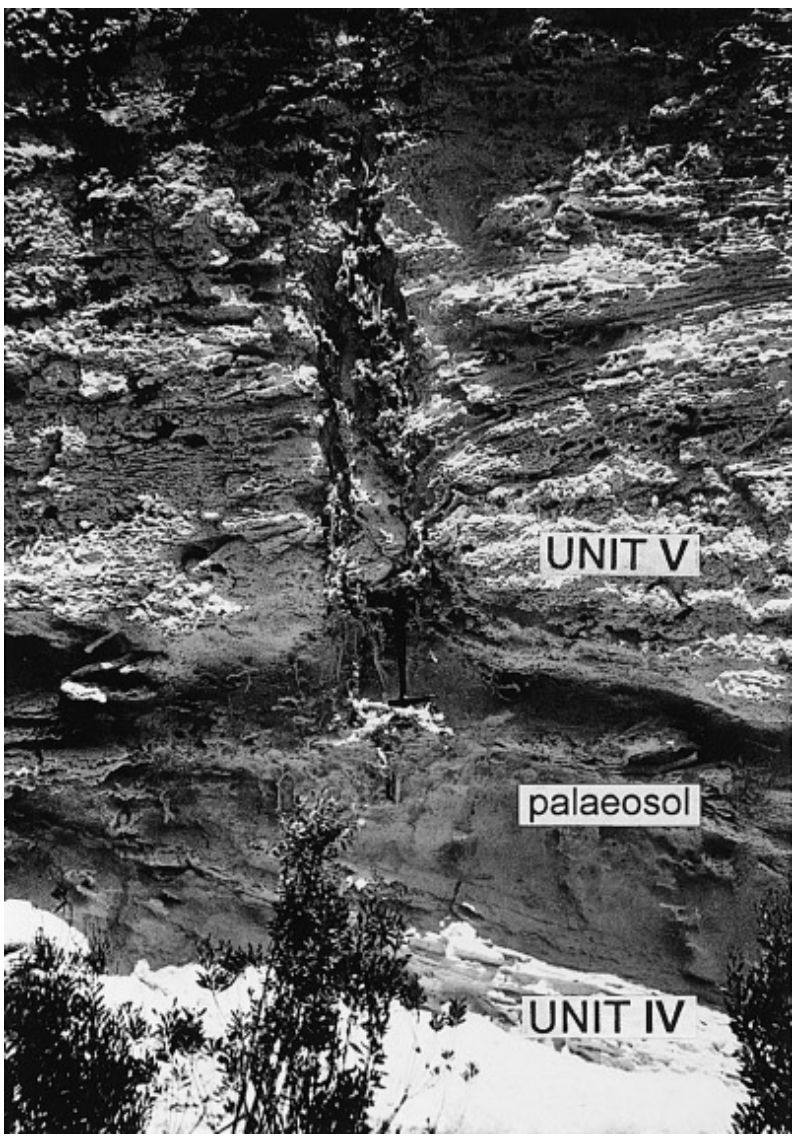

Fig. 11. Two Pines section (Eleuthera). A thick sandy palaeosol supporting a fossil trunk separates the early (Unit IV) and late (Unit V) substage 5e oolites. Scale is given by the hammer at the base of fossil tree. Entombing of standing trees and leafy vegetation suggests a rapid rate of deposition for Unit $\mathrm{V}$.

include fenestral voids possibly caused by heavy rainfall (Bain \& Kindler, 1994) that must not be confused with swash-induced fenestrae.

Substage 5e oolites differ in their stratigraphic and morphostratigraphic position, petrological composition and amino-acid content (Table 2; Hearty \& Kindler, 1993a, 1994). Unit IV is found at the base of the last interglacial stratigraphic sections (Sites 26 and 57, Fig. 3) and in a more Iandward position than Unit $V$. In vertical successions, a thick sandy palaeosol commonly separates the aeolian facies of these deposits (Fig. 11). Field evidence also shows that Unit IV pre-dates or is coeval with early Sangamonian reefs, whereas Unit $\mathrm{V}$ clearly post-dates them (Fig. 12). Both units are oolites, but the younger one usually contains a higher proportion of bioclasts and aggregates (Table 6, Fig. 14) than the older one (Table 5, Fig. 13). The most common constituent grains are tangential-aragonitic ooids and peloids
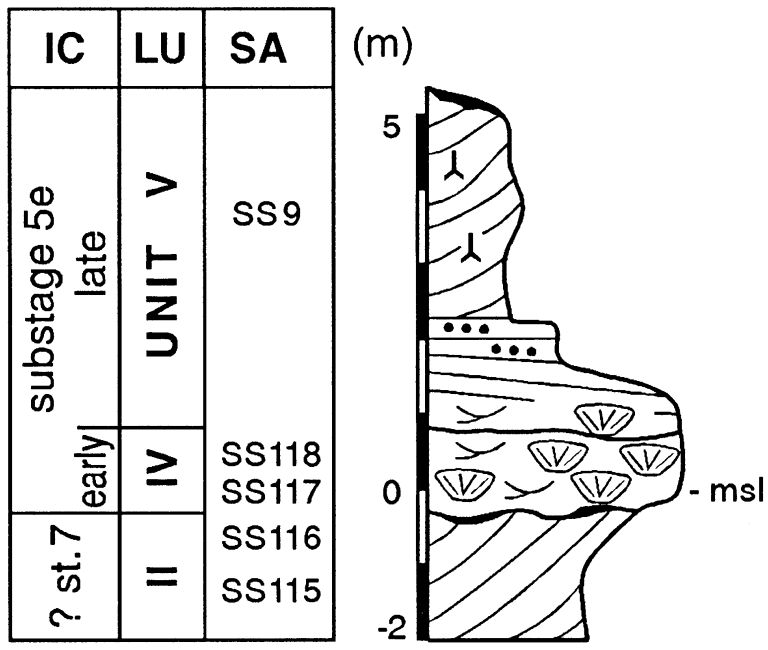

\section{$Q 7$ eolian foresets \\ $\because$ beach bedding \& fenestrae $\triangle$ trough cross-bedding \\ (v) reef facies \\ [ d r rizoliths calcrete}

Fig. 12. Grotto Beach section (San Salvador, Site 38, Fig. 3). IC=isotope chronology; $L U=$ ithostratigraphic unit; SA =sample number. Pre-Sangamonian aeolianites (Unit II) are overlain by early Sangamonian deposits. A discontinuity within the fossil reef shows that Unit IV (reef facies) and Unit V (shallowing-upward sequence from reef to aeolian facies) are represented at this location.

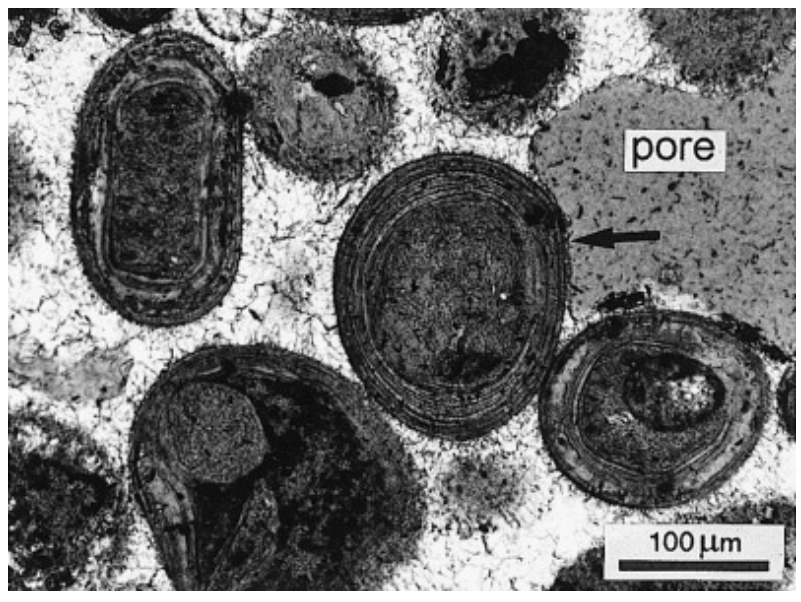

Fig. 13. Sample EL 83, Unit IV, The Cliffs, El euthera. Microfacies of the early substage $5 e$ ool ite. Note thickly coated ooids (arrow) and coarse sparry cement.

that still preserve their original mineralogy. Ooids typically show thick cortices (up to $100 \mu \mathrm{m}$, Fig. 13) and small peloidal nuclei. Superficial ooids (Illing, 1954) also occur, but are less abundant than in middle Holocene oolites. Peculiar radial ooids have also been observed in several samples collected from El euthera (Kindler \& Hearty, 1995, fig. 4 e). In both units, allochems are bound by 


\begin{tabular}{lccccccc}
\hline$\%$ & $\begin{array}{c}\text { ABI } \\
(4)\end{array}$ & $\begin{array}{c}\text { BIM } \\
(1)\end{array}$ & $\begin{array}{c}\text { NPI } \\
(11)\end{array}$ & $\begin{array}{c}\text { ELU } \\
(13)\end{array}$ & $\begin{array}{c}\text { CAT } \\
(3)\end{array}$ & $\begin{array}{r}\text { SSI } \\
(12)\end{array}$ & $\begin{array}{c}\text { EXU } \\
(5)\end{array}$ \\
\hline Grains & $60 \cdot 7$ & $53 \cdot 8$ & $61 \cdot 1$ & $62 \cdot 5$ & $63 \cdot 5$ & $65 \cdot 8$ & $65 \cdot 8$ \\
Pores & $9 \cdot 4$ & $28 \cdot 8$ & $16 \cdot 1$ & $10 \cdot 2$ & $13 \cdot 8$ & $12 \cdot 2$ & $13 \cdot 0$ \\
Cement & $30 \cdot 0$ & $17 \cdot 4$ & $22 \cdot 7$ & $27 \cdot 3$ & $22 \cdot 7$ & $22 \cdot 0$ & $21 \cdot 2$ \\
Biocl. & $2 \cdot 2$ & $3 \cdot 4$ & $2 \cdot 6$ & $2 \cdot 9$ & $5 \cdot 7$ & $4 \cdot 7$ & $5 \cdot 0$ \\
Ooids & $73 \cdot 2$ & $63 \cdot 1$ & $73 \cdot 6$ & $61 \cdot 8$ & $56 \cdot 7$ & $70 \cdot 8$ & $55 \cdot 3$ \\
Pel oids & $21 \cdot 9$ & $20 \cdot 5$ & $18 \cdot 5$ & $25 \cdot 1$ & $33 \cdot 3$ & $20 \cdot 1$ & $26 \cdot 6$ \\
Misc. & $2 \cdot 8$ & $13 \cdot 0$ & $5 \cdot 3$ & $10 \cdot 2$ & $4 \cdot 4$ & 4.5 & $13 \cdot 0$ \\
S ratio & 0.022 & 0.039 & 0.028 & 0.032 & 0.060 & 0.049 & 0.058
\end{tabular}

Table 5. Petrographic characteristics of Unit IV (early substage 5e oolite). Abbreviations are the same as for Table 3. Very low skeletal ratios indicate the predominance of ooids and peloids over bioclasts.

\begin{tabular}{|c|c|c|c|c|c|c|}
\hline$\%$ & $\begin{array}{c}A B I \\
(3)\end{array}$ & $\begin{array}{c}\text { BIM } \\
\text { (3) }\end{array}$ & $\begin{array}{c}\text { NPI } \\
\text { (8) }\end{array}$ & $\begin{array}{c}\text { ELU } \\
\text { (3) }\end{array}$ & $\begin{array}{l}\text { SSI } \\
\text { (15) }\end{array}$ & $\begin{array}{c}\text { EXU } \\
\text { (1) }\end{array}$ \\
\hline $\begin{array}{l}\text { Grains } \\
\text { Pores } \\
\text { Cement }\end{array}$ & $\begin{array}{l}62 \cdot 8 \\
12 \cdot 5 \\
24 \cdot 7\end{array}$ & $\begin{array}{l}65 \cdot 7 \\
14 \cdot 7 \\
19 \cdot 5\end{array}$ & $\begin{array}{l}65 \cdot 2 \\
18 \cdot 9 \\
16 \cdot 0\end{array}$ & $\begin{array}{l}62 \cdot 3 \\
17 \cdot 9 \\
19 \cdot 8\end{array}$ & $\begin{array}{r}63 \cdot 6 \\
26 \cdot 8 \\
9.7\end{array}$ & $\begin{array}{l}69.6 \\
19.6 \\
10.8\end{array}$ \\
\hline $\begin{array}{l}\text { Biocl. } \\
\text { Ooids } \\
\text { Pel oids } \\
\text { Misc. }\end{array}$ & $\begin{array}{r}12 \cdot 3 \\
52 \cdot 9 \\
30.9 \\
3.9\end{array}$ & $\begin{array}{l}20 \cdot 8 \\
50 \cdot 8 \\
16 \cdot 3 \\
12 \cdot 0\end{array}$ & $\begin{array}{r}9.6 \\
43 \cdot 0 \\
21 \cdot 5 \\
25 \cdot 9\end{array}$ & $\begin{array}{r}26 \cdot 6 \\
38 \cdot 0 \\
28 \cdot 3 \\
7 \cdot 2\end{array}$ & $\begin{array}{l}19 \cdot 0 \\
40 \cdot 6 \\
28 \cdot 8 \\
11 \cdot 3\end{array}$ & $\begin{array}{l}13 \cdot 1 \\
42 \cdot 9 \\
26 \cdot 1 \\
17 \cdot 9\end{array}$ \\
\hline S ratio & 0.128 & 0.237 & 0.130 & 0.286 & 0.215 & $0 \cdot 160$ \\
\hline
\end{tabular}

Table 6. Petrographic characteristics of Unit V (Iate substage 5 e oolite). Abbreviations are the same as for Table 3. Bioclasts are more abundant than in slightly older Unit IV (Table 5). coarse LMC equant spar which either occurs at grain contacts or totally fills pore spaces. Cement may represent up to $30 \%$ of the rock volume in Unit IV and around $15 \%$ in Unit V (Tables 5 and 6). For both units, the degree of cementation seems to correlate with sample location. Cement percentages tend to be higher in samples collected

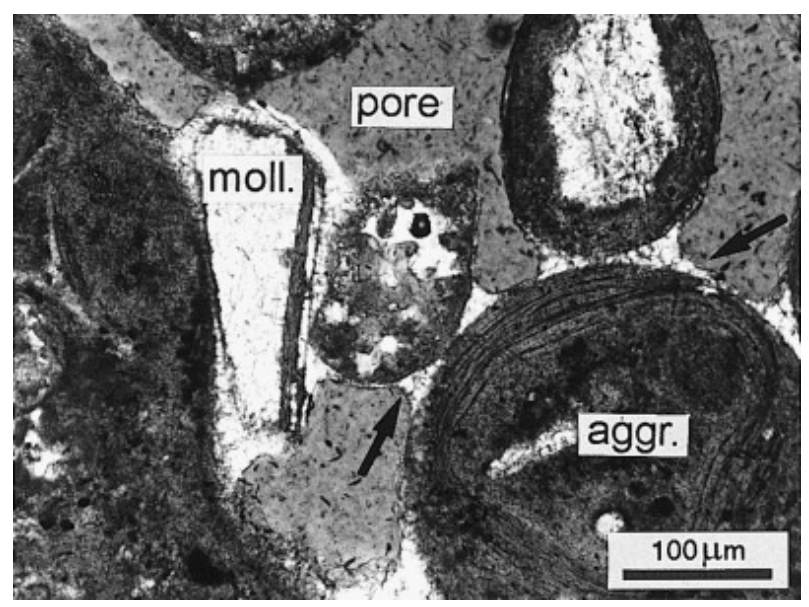

Fig. 14. Sample SS 9, Unit V, Grotto Beach, San Sal vador. Microfacies of the late substage $5 e$ oolite; (aggr.)=aggregate grain; (moll.)=mollusc fragment. Menisci (arrows) at grain contacts indicate that early diagenesis took place in a freshwater vadose environment. from the northern islands (e.g. Abaco) than in those gathered from southern locations (e.g. Cat, San Sal vador). This cementati on trend mi rrors the northward increase in the amount of annual rainfall and associated leaching in this region (Pierson \& Shinn, 1985).

The ages of the early Sangamonian oolites are estimated at c. 135000 and 120000 yr BP (see Fig. $20)$, respectively, based on their relative position with respect to well-dated substage $5 e$ reefs and AAR analyses (Table 2; Hearty \& Kindler, 1993a). These units differ petrographically from middle Pleistocene oolites by a lesser degree of diagenetic alteration and from Holocene oolites by the abundance of thickly coated ooids.

\section{Unit VI - late Sangamonian bioclastic calcarenites (isotope stage 5a)}

Late stage 5 deposits were recently defined on the eastern shoreline of San Salvador by Hearty \& Kindler (1993a, 1994) and correlated with the Southampton Formation in Bermuda (Vacher \& Hearty, 1989). Similar deposits have since been identified in Abaco (Sites 46 and 49, Fig. 3), Bimini (Site 2, Fig. 3), Eleuthera (Site 54, Fig. 3) and New Providence (Site 19, Fig. 3), where they form coastal bluffs and promontories that are 


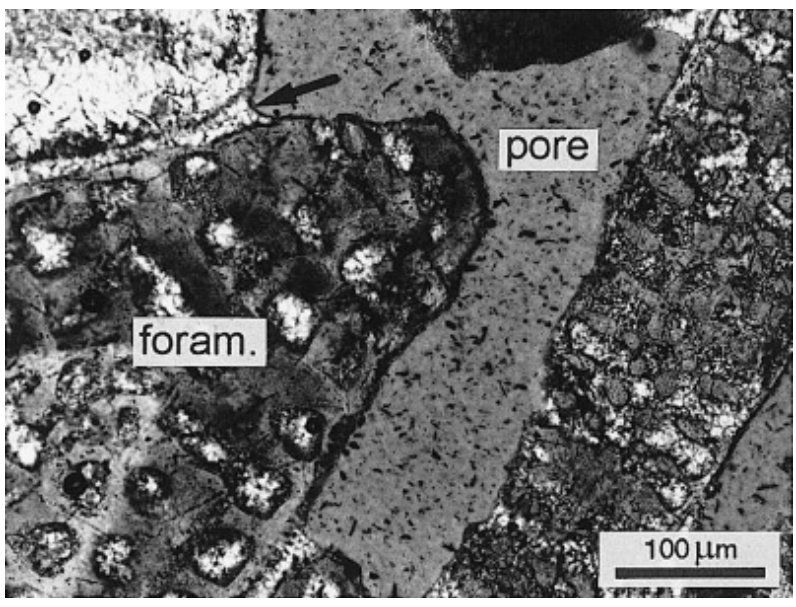

Fig. 15. Sample SS 69, Unit VI, Almgreen Cay (San Sal vador, Site 33, Fig. 3). Microfacies of substage $5 a$ bioclastic cal carenite. Note high primary porosity and sparse 'grain-skin' cement (arrow) at grain contacts; (foram.) $=$ foraminifer fragment.

always situated close to the platform margin. These landforms commonly display abundant rhizoliths and large ( $>5 \mathrm{~m})$, steep foresets that systematically dip below modern sea level. Unit VI can thus be interpreted as partly eroded aeolian dunes deposited when sea level was lower than today. Except for a few basal samples that contain ooids, probably reworked from early Sangamonian deposits, Unit VI calcarenites principally consist of bioclastic fragments characteristic of a high-energy marine setting, such as coral and red algae debris (Fig. 15, Table 7). These allochems are loosely bound by sparse (average $3 \%$, Table 7), finely crystallized sparry cement, mostly found at grain contacts. Diagenetic features, such as empty micrite envelopes or recrystallized grains, are virtually absent from the studied samples, which may still contain traces of high-Mg cal cite (HMC).

A substage 5a (c. $80 \mathrm{ka}$ BP, see Fig. 20) age can be attributed to Unit VI on the basis of: (1) its stratigraphic position between two palaeosols, a lower one overlying substage 5e oolites (Fig. 16) and an upper one underlying Holocene units; (2) its location close to the bank edges indicating deposition during a modest transgressive event; (3) the small amount of diagenetic al teration of samples; and (4) low A/I ratios (Table 2; Hearty \& Kindler, 1993a, 1994). These deposits can be recognized from middle Pleistocene bioclastic calcarenites (Units II and III) by a lesser degree of diagenetic alteration and from late Holocene skeletal limestones (Unit VIII) by the absence of associated beach facies.

\section{Units VII and VIII - Holocene oolites and bioclastic calcarenites (isotope stage 1)}

Unit VII is a volumetrically small rock body that was first identified on San Salvador (North Point Member, Carew \& Mylroie, 1985; Hearty \& Kindler, 1993a; Site 30, Fig. 3). It also occurs on Little San Salvador and West Plana Cay (Wilber, 1987) and, more recently, it was studied on Lee Stocking Island (Exuma Chain; Dune Pass Bay oolite, Kindler, 1995; Sites 12 and 16, Fig. 3) and Cat (Kindler, 1992; Site 7, Fig. 3). We have further recognized comparable deposits on Abaco (Site 48, Fig. 3), New Providence and Eleuthera (Site 58, Fig. 3). Unit VII consists of oolitic-peloidal limestones, which usually form 4-8-m-high 'haystack' dunes. These limestones show pristine small-scale aeolian structures, such as sandflow cross-strata, wind-ripple and grainfall strata (White \& Curran, 1988; Caputo, 1993). Systematic occurrence of these wind-induced sedimentary structures in the modern subtidal zone clearly indicates that Unit VII was deposited when sea level was lower than today (see Fig. 20). This assumption is consistent with the c. 5-ka radiometric age obtained from these oolites (Carew \& Mylroie, 1987; Kindler, 1992). Despite its young age, Unit VII is fairly well lithified. Sparry cement
Table 7. Petrographic characteristics of Unit VI (substage 5 a bi oclastic cal carenites). Abbreviations are the same as for Table 3. Note the small percentages of cement.

\begin{tabular}{lccccr}
\hline \% & $\begin{array}{c}\text { ABI } \\
(1)\end{array}$ & $\begin{array}{c}\text { BIM } \\
(1)\end{array}$ & $\begin{array}{c}\text { NPI } \\
(3)\end{array}$ & $\begin{array}{c}\text { ELU } \\
(7)\end{array}$ & \multicolumn{1}{c}{$\begin{array}{r}\text { SSI } \\
(8)\end{array}$} \\
\hline Grains & 53.3 & 54.7 & 60.7 & 61.1 & 61.0 \\
Pores & 42.8 & 43.9 & 35.7 & 34.7 & 37.6 \\
Cement & 3.9 & 1.4 & 3.6 & 4.2 & 1.5 \\
Biocl. & 88.8 & 74.4 & 65.5 & 86.7 & 78.8 \\
Ooids & 0.0 & 0.5 & 2.6 & 0.7 & 3.8 \\
Peloids & 10.1 & 18.6 & 10.3 & 7.3 & 10.3 \\
Misc. & 1.1 & 6.5 & 21.6 & 5.3 & 7.2 \\
S ratio & 0.898 & 0.796 & 0.835 & 0.915 & 0.848 \\
& & & & & \\
\hline
\end{tabular}




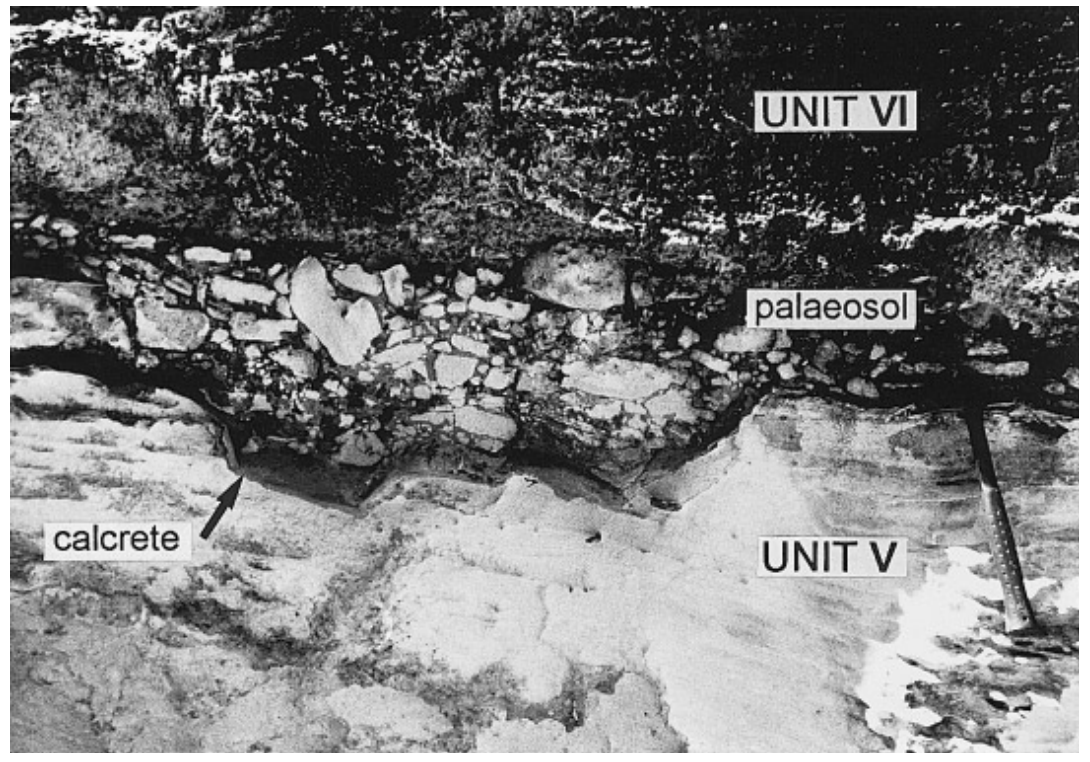

\begin{tabular}{|c|c|c|c|c|c|c|}
\hline$\%$ & $\begin{array}{c}A B I \\
(3)\end{array}$ & $\begin{array}{c}\text { NPI } \\
(2)\end{array}$ & $\begin{array}{c}\text { ELU } \\
\text { (3) }\end{array}$ & $\begin{array}{c}\text { CAT } \\
\text { (2) }\end{array}$ & $\begin{array}{l}\text { SSI } \\
\text { (7) }\end{array}$ & $\begin{array}{l}\text { EXU } \\
\text { (14) }\end{array}$ \\
\hline $\begin{array}{l}\text { Grains } \\
\text { Pores } \\
\text { Cement }\end{array}$ & $\begin{array}{l}62 \cdot 3 \\
24 \cdot 1 \\
13 \cdot 6\end{array}$ & $\begin{array}{l}57 \cdot 6 \\
22 \cdot 3 \\
20 \cdot 2\end{array}$ & $\begin{array}{l}62 \cdot 7 \\
17 \cdot 7 \\
19 \cdot 6\end{array}$ & $\begin{array}{l}66 \cdot 3 \\
14 \cdot 7 \\
19 \cdot 0\end{array}$ & $\begin{array}{l}63 \cdot 9 \\
23 \cdot 4 \\
12 \cdot 8\end{array}$ & $\begin{array}{l}65 \cdot 4 \\
19 \cdot 0 \\
15 \cdot 6\end{array}$ \\
\hline $\begin{array}{l}\text { Biocl. } \\
\text { Ooids } \\
\text { Pel oids } \\
\text { Misc. }\end{array}$ & $\begin{array}{r}5.9 \\
77 \cdot 6 \\
14 \cdot 1 \\
2.5\end{array}$ & $\begin{array}{l}11 \cdot 2 \\
52 \cdot 3 \\
21 \cdot 0 \\
15 \cdot 5\end{array}$ & $\begin{array}{r}13 \cdot 7 \\
47 \cdot 3 \\
33 \cdot 8 \\
5 \cdot 1\end{array}$ & $\begin{array}{r}1 \cdot 5 \\
74 \cdot 6 \\
17 \cdot 8 \\
6 \cdot 2\end{array}$ & $\begin{array}{r}8.0 \\
53.7 \\
30.9 \\
7.4\end{array}$ & $\begin{array}{r}9 \cdot 9 \\
68 \cdot 3 \\
14 \cdot 5 \\
7 \cdot 3\end{array}$ \\
\hline S ratio & 0.060 & 0.133 & 0.145 & 0.016 & 0.087 & $0 \cdot 106$ \\
\hline
\end{tabular}

Fig. 16. Roadcut near The Cliffs section, El euthera, showing the vertical succession of Units $V$ (late substage $5 e$ oolite) and VI (substage 5 a bioclastic calcarenite). The red brecciated pal aeosol, 0.5-cm-thick cal crete and karstified surface on the top of Unit $V$ show that a considerable amount of time elapsed before deposition of Unit VI.

Table 8. Petrographic characteristics of Unit VII (middle Holocene oolite). A bbreviations are the same as for Table 3. may represent up to $20 \%$ of the rock volume (Table 8). Complete or partial leaching of ooid cortices also occurs, which is unusual for Hol ocene carbonates (Gavish \& Friedman, 1969). These limestones differ petrographically from older oolites (Units I, IV and V) by the predominance of superficial ooids consisting of large, usually peloidal, nuclei and thin cortices (Fig. 17).

Late Hol ocene skel etal cal carenites occur extensively on the Bahamas islands. Initially defined on San Salvador (Hanna Bay Member, Carew \& Mylroie, 1985), they have al so been reported from the Exuma Chain (Perry Peak limestone, Kindler, 1995; Sites 14, 15, 17, Fig. 3), Cat (Kindler, 1992; Site 10, Fig. 3) and Bimini (Strasser \& Davaud, 1986; Site 4, Fig. 3). In addition, we have recently examined similar deposits on Abaco, Eleuthera and New Providence (Sites 28, 46, 53, 56, 59, Fig. $3)$. Biogenic and primary sedimentary structures show that Unit VIII was formed in shallow-

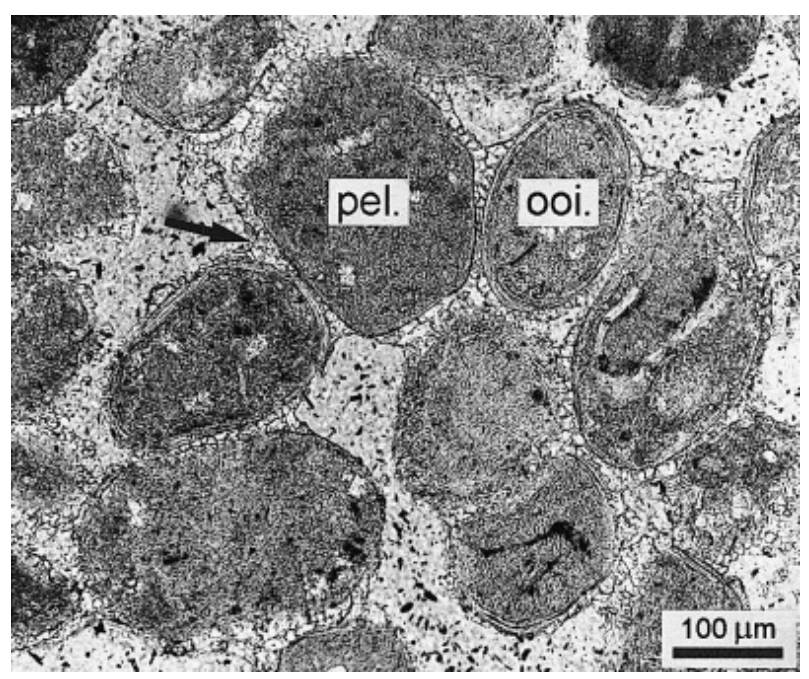

Fig. 17. Sample LSI 1, Unit VII, Dune Pass Bay, Lee Stocking Island (Exumas, Site 12, Fig. 3). Microfacies of the middle Holocene oolite. Note superficial ooids (ooi.), peloids (pel.) and patchy coarse spar cement forming menisci at grain contacts (arrow). 
Fig. 18. Paradise Point, North Bimini (Site 4, Fig. 3).

Shallowing-upward sequence in Unit VIII from foreshore to aeolian deposits. Note that the fossil (exhumed) beach is congruent with modern sea-level stand. Person is $1.65 \mathrm{~m}$ tall.

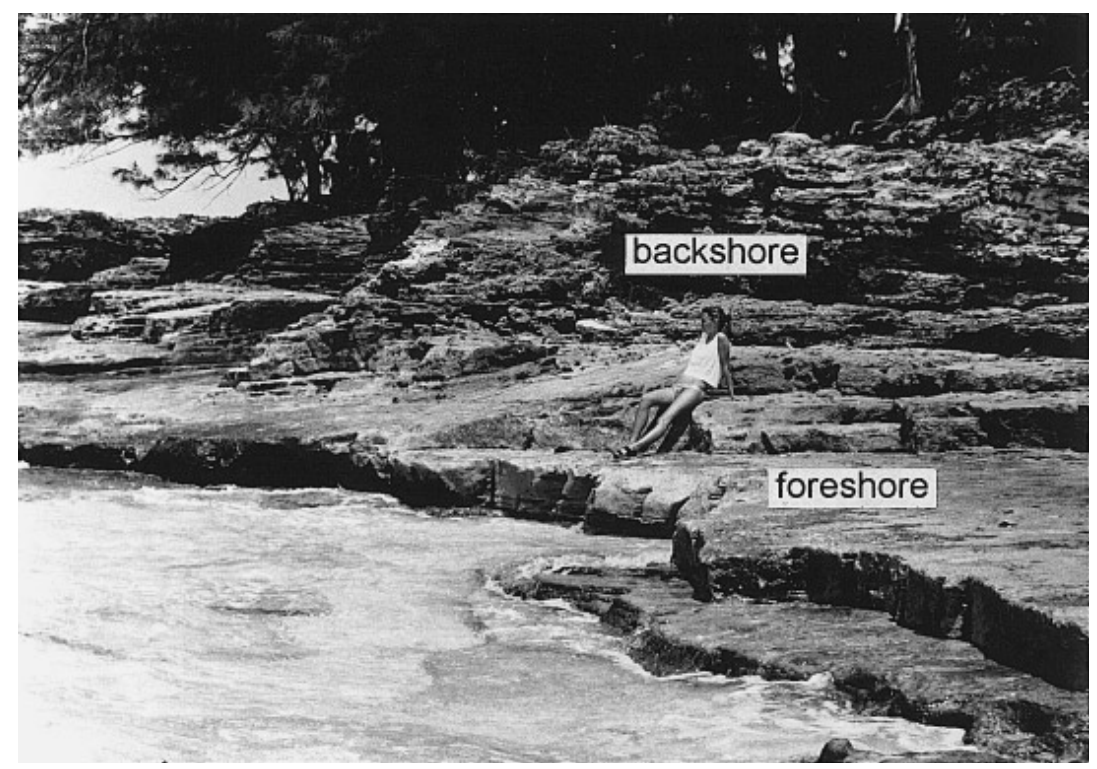

marine, beach and aeolian environments when sea level was close to its present elevation (see Fig. 20). Indeed, exhumed or 're-exposed' beaches (Strasser \& Davaud, 1986) consisting of wellcemented bioclastic calcarenite frequently occur in the modern intertidal zone (Fig. 18). This unit is composed of friable to well-lithified, yellowish bioclastic limestones containing coral, al gal and mollusc debris (Fig. 19), as well as abundant fragments of the pink foraminifer Homotrema rubrum. Relative abundance of bioclasts is usually lower than for Pleistocene skel etal eolianites (Table 9) because of frequent reworking of

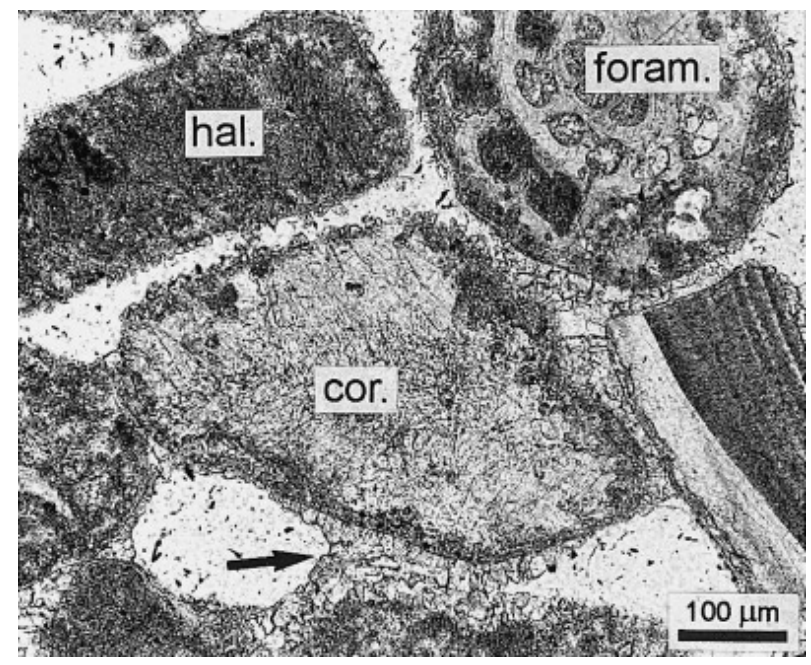

Fig. 19. Sample LSI 2, Unit VIII, Beach Cottage, Lee Stocking Isl and (Exumas, Site 14, Fig. 3). Microfacies of the late Holocene bioclastic calcarenites. Note coral (cor.), foraminifer (foram.) and micritized Halimeda (hal.) fragments. Arrow points to patchy sparry cement. ooids and peloids from middle Holocene deposits. Late Hol ocene bi ocl astic cal carenites have been cemented by freshwater LMC cements following phases of shoreline progradation (Strasser $\&$ Davaud, 1986). Cement may reach $10 \%$ of the rock volume in the beach facies, but sel dom more than $5 \%$ in the associated aeolianites. A second generation of recent marine cement commonly occurs within Unit VIII rocks now exposed in the intertidal zone (Kindler \& Bain, 1993). In San Sal vador, wholerock ${ }^{14} \mathrm{C}$ analyses on the Hanna Bay Member yielded ages between 3200 and 420 yr вP (Carew \& Mylroie, 1987; Kindler \& Bain, 1993). Likewise, Gifford (1973) reported ages of $2300 \mathrm{yr}$ BP from similar deposits in Bimini. However, an age of $5070 \pm 70 \mathrm{yr}$ BP was measured from one sample collected from the cliffs situated to north of Dune Pass on Lee Stocking Island (Site 15, Fig. 3). We speculate that this apparently anomal ous age could be in part related to the high percentage of reworked ooids (26.5\%) and peloids $(46.9 \%)$ within this particular sample. The aeolian facies of Unit VIII differs from its Pleistocene counterparts (Units II, III and VI) by the occurrence of associated marine facies and a lesser stage of diagenetic alteration.

\section{DISCUSSION}

\section{Petrography of Bahamian stratigraphic units}

Two major points emerge from the petrographic data presented earlier, summarized in Table 10. 
Table 9. Petrographic characteristics of U nit VIII (late Hol ocene bi oclastic cal carenite). A bbreviati ons are the same as for Table 3. Relative percentages of bioclasts tend to be lower than for Pleistocene skel etal cal carenites due to the common reworking of ooids and peloids from Unit VII.

\begin{tabular}{|c|c|c|c|c|c|c|c|}
\hline$\%$ & $\begin{array}{c}\text { ABI } \\
\text { (1) }\end{array}$ & $\begin{array}{c}\text { BIM } \\
\text { (3) }\end{array}$ & $\begin{array}{l}\text { NPI } \\
\text { (3) }\end{array}$ & $\begin{array}{c}\text { ELU } \\
\text { (5) }\end{array}$ & $\begin{array}{c}\text { CAT } \\
\text { (2) }\end{array}$ & $\begin{array}{l}\text { SSI } \\
\text { (11) }\end{array}$ & $\begin{array}{l}\text { EXU } \\
\text { (19) }\end{array}$ \\
\hline $\begin{array}{l}\text { Grains } \\
\text { Pores } \\
\text { Cement }\end{array}$ & $\begin{array}{r}64 \cdot 0 \\
31 \cdot 0 \\
5 \cdot 0\end{array}$ & $\begin{array}{r}63 \cdot 3 \\
30 \cdot 1 \\
6 \cdot 7\end{array}$ & $\begin{array}{r}67 \cdot 8 \\
24 \cdot 5 \\
7 \cdot 7\end{array}$ & $\begin{array}{r}60 \cdot 5 \\
34 \cdot 5 \\
5 \cdot 0\end{array}$ & $\begin{array}{r}66 \cdot 0 \\
27 \cdot 2 \\
6 \cdot 9\end{array}$ & $\begin{array}{r}62 \cdot 2 \\
28 \cdot 7 \\
9 \cdot 2\end{array}$ & $\begin{array}{r}63 \cdot 8 \\
31 \cdot 1 \\
5 \cdot 1\end{array}$ \\
\hline $\begin{array}{l}\text { Biocl. } \\
\text { Ooids } \\
\text { Pel oids } \\
\text { Misc. }\end{array}$ & $\begin{array}{l}43 \cdot 3 \\
24 \cdot 2 \\
18 \cdot 5 \\
14 \cdot 0\end{array}$ & $\begin{array}{r}64.9 \\
1.9 \\
14.8 \\
18.4\end{array}$ & $\begin{array}{r}84 \cdot 2 \\
2 \cdot 0 \\
8 \cdot 1 \\
5 \cdot 8\end{array}$ & $\begin{array}{r}74 \cdot 2 \\
11 \cdot 2 \\
11 \cdot 5 \\
3 \cdot 1\end{array}$ & $\begin{array}{r}60 \cdot 1 \\
16 \cdot 0 \\
19 \cdot 7 \\
4 \cdot 2\end{array}$ & $\begin{array}{r}50 \cdot 9 \\
24 \cdot 1 \\
17 \cdot 2 \\
7 \cdot 9\end{array}$ & $\begin{array}{l}59 \cdot 8 \\
13 \cdot 4 \\
16 \cdot 3 \\
10 \cdot 6\end{array}$ \\
\hline S ratio & 0.531 & 0.762 & 0.916 & 0.766 & 0.748 & 0.615 & 0.714 \\
\hline
\end{tabular}

Table 10. Comparative petrography of Bahamian Quaternary units. Skeletal rati os obtained in Tables 3-9 are placed in cells defined by islands (col umns: $\mathrm{ABI}=\mathrm{A}$ baco; $\mathrm{BIM}=\mathrm{Bimini}$; $\mathrm{NPI}=\mathrm{New}$ Providence; $\mathrm{ELU}=$ El euthera; $\mathrm{CAT}=\mathrm{Cat}$; SSI =San Salvador; EXU =Exumas) and stratigraphic units (rows: I-VIII, as in Table I). Coeval units have a similar petrographic composition on each of the studied islands, e.g. values of skeletal ratios (obtained by dividing the percentage of bioclasts by the total percentage of bioclasts, peloids and ooids) for Unit I vary between 0.057 (CAT) and 0.175 (ELU). Two groups of contrasting lithologies can be defined. The first group (Units II, III, VI and VIII) is dominated by skel etal fragments (ratios greater than 0.50). The other one (Units I, IV, V and VII) is characterized by the predominance of ooids and peloids (ratios smaller than $0 \cdot 25$ ).

\begin{tabular}{|c|c|c|c|c|c|c|c|}
\hline Unit & $A B I$ & BIM & $\mathrm{NPI}$ & ELU & CAT & SSI & EXU \\
\hline $\begin{array}{l}\text { VIII } \\
\text { VII }\end{array}$ & $\begin{array}{l}0.531 \\
0.060\end{array}$ & 0.762 & $\begin{array}{l}0.916 \\
0.133\end{array}$ & $\begin{array}{l}0.766 \\
0.145\end{array}$ & $\begin{array}{l}0.748 \\
0.016\end{array}$ & $\begin{array}{l}0.615 \\
0.087\end{array}$ & $\begin{array}{l}0.714 \\
0 \cdot 106\end{array}$ \\
\hline $\begin{array}{l}\text { VI } \\
\text { V } \\
\text { IV }\end{array}$ & $\begin{array}{l}0.898 \\
0.128 \\
0.022\end{array}$ & $\begin{array}{l}0.796 \\
0.237 \\
0.039\end{array}$ & $\begin{array}{l}0.835 \\
0.130 \\
0.028\end{array}$ & $\begin{array}{l}0.915 \\
0.286 \\
0.032\end{array}$ & 0.060 & $\begin{array}{l}0.848 \\
0.215 \\
0.049\end{array}$ & $\begin{array}{l}0.160 \\
0.058\end{array}$ \\
\hline$\| / I I I$ & 0.786 & & 0.654 & 0.898 & 0.867 & 0.794 & 0.901 \\
\hline 1 & 0.147 & & 0.074 & 0.175 & 0.057 & 0.082 & \\
\hline
\end{tabular}

First, as shown by the values of skel etal ratios, coeval stratigraphic units have a comparable petrographic composition throughout the study area. In other words, the studied limestone units form a similar lithostratigraphic sequence on each of these widely spaced islands. When complete, this sequence includes at least one middle Pleistocene oolite, two skeletal units of stage 7 age, two early Sangamonian oolites, one substage 5 a bi oclastic calcarenite, and two Holocene units. Further analysis of Table 10 shows that the lithostratigraphic units exposed on the Bahamas islands can be separated into two groups presenting contrasting lithologies. The first group (Units II, III, VI and VIII) is dominated by bioclasts (skel etal rati os greater than 0.50). The other group (Units I, IV, V and VII) is characterized by the predominance of tangential-aragonitic ooids and pel oids (skeletal ratios smaller than 0.25). Before further discussion, the factors controlling the formation of ooids and bioclasts must be clear.

Most authors (e.g. Newell et al., 1960; Simone, 1981; Richter, 1983) agree that conditions required for optimal production of tangentialaragonitic ooids are: (1) a flat topography where particl es can remain in their formati on locus; (2) a very shallow and potentially turbulent environment; (3) a mixture of cool, $\mathrm{CO}_{2}$-rich, oceanic water and warm bank-water supersaturated with respect to aragonite. Factors favouring reef growth, and thus indirectly bioclast production, are: (1) a hard substrate, (2) a high-energy setting, (3) shallow to moderate depths (up to $20 \mathrm{~m}$ ), (4) normal-salinity, low-turbidity waters and (5) water temperatures between 20 and $30{ }^{\circ} \mathrm{C}$ (Newell \& Rigby, 1957; Voss, 1988). Both grain types thus form close to the platform margins (Hine, 1977; Demicco \& Hardie, 1994); however, ooid 


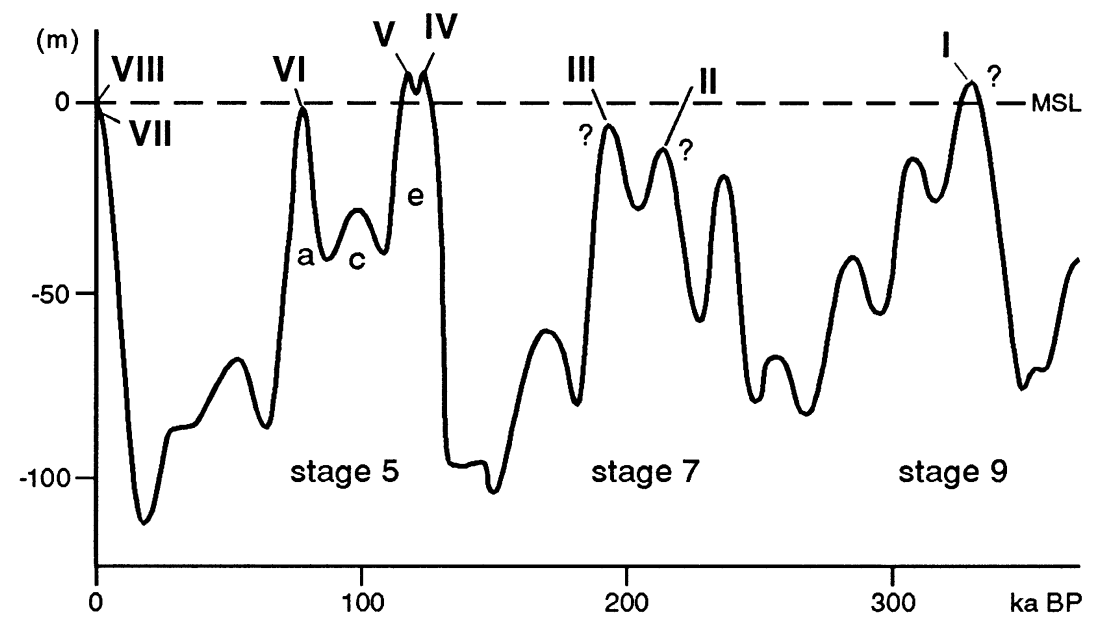

Fig. 20. Location of the studied units on a late Quaternary sea-level curve modified from Imbrie et al. (1984). Units I, II and III pre-date the Sangamonian period. Unit I was formed when sea level was higher than present, probably during isotopic stage 9. Units II and III were deposited during lower sea-level stands that could correspond to distinct transgressive phases during isotope stage 7. The Sangamonian record includes Units IV (early substage 5e), V (I ate 5e) and VI (substage 5a). As shown in Bermuda (Vacher \& Hearty, 1989), the 5a sea-level event reached higher than indicated by the isotopic record from deep-sea sediments. The Holocene record consists of Units VII and VIII deposited during the early transgression and stillstand, respectively.

formation requires flooding of the platform top, whereas marginal reefs anchored on the platform slopes may produce bioclasts during relative sea-level lowstands.

\section{Petrography and sea level}

The petrographic composition of the Bahamian stratigraphic units is related to past sea-level elevation (Fig. 20). Except for Unit VII, ooliticpel oidal deposits (Units I, IV and V) were formed when sea level was higher than today, as shown by the occurrence of perched beach and shoreface facies. In contrast, bioclastic formations (Units II, III, VI and VIII) accumulated when sea level was equival ent to, or lower than, modern ordnance datum (Fig. 7). Due to the wide extension of the described units $(700 \times 450 \mathrm{~km})$, regional, if not global, factors must be invoked to explain this relationship. We think that the degree of platform flooding ultimately controlled the petrography of the limestones now exposed on the Bahamas islands. When the platform was only marginally flooded (Fig. 21a), conditions were unfavourable to ooid production because of the absence of an extensive layer of shallow water on the bank top. In contrast, reefs, which do not require a wide surface for growth, could thrive on the bank slopes just bel ow the platform edges and produce bioclasts. These particles formed coastal deposits near the bank margins, which are partially submerged today. Such was the case for isotope stage
7 and substage 5a bioclastic cal carenites. During complete flooding (Fig. 21c), warm, saline and actively circulating bank waters were del eterious to reef growth, but stimulated ooid and peloid production on the platforms. These particles formed shallowing-upward sequences from subtidal to aeolian facies that are now found above modern ordnance datum. The middle Pleistocene and substage $5 e$ oolites typically show such el evated sequences. Stage 1 conditions seem to be intermediate between the extreme cases described (Fig. 21b). Although the banks are flooded today, and although ooid production is locally significant (e.g. Joulters Cays, Harris, 1979), water circulation is somehow restricted and the bulk of sediments supplied to islands consists of bioclastic particles produced by marginal reefs. The middle Holocene oolite (Unit VII) corresponds to an early transgressive event (Kindler, 1992, 1995) that is presently being eroded and will probably not be preserved in the geological record. Similar events probably occurred during isotope stage 7 and substage $5 \mathrm{a}$, but may just be recorded by a higher proportion of ooids in the lowermost beds of the bioclastic calcarenites deposited during those time periods. Skeletal limestones are thus truly representative of isotope stage 1 sedimentation.

\section{Petrography and climate}

Because of the quiescent tectonic setting in the Bahamas (Lynts, 1970; Mullins \& Lynts, 1977), 
a) PARTIAL FLOODING

(arid climate)

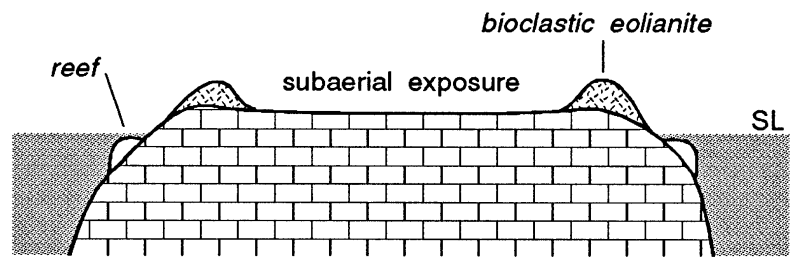

BIOCLASTS DOMINATE SEDIMENTATION

b) TODAY

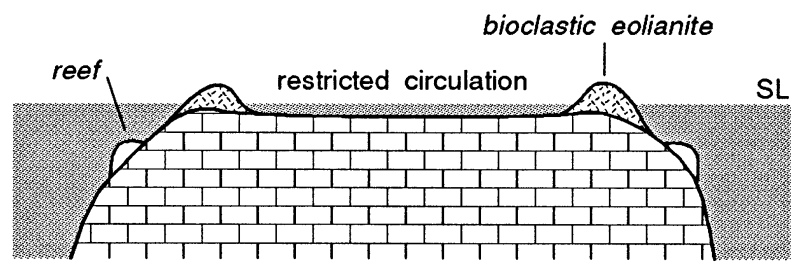

BIOCLASTS DOMINATE SEDIMENTATION

c) TOTAL FLOODING

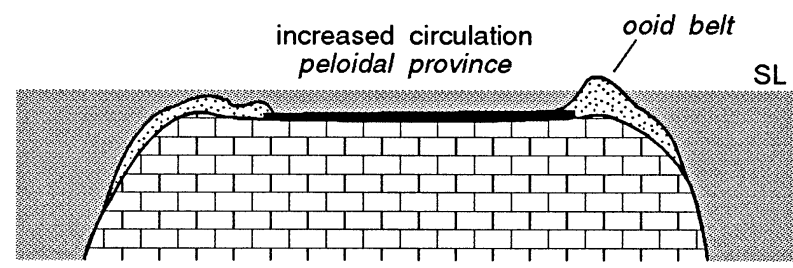

OOIDS \& PELOIDS DOMINATE SEDIMENTATION

Fig. 21. Model showing the relationship between sealevel changes and the petrographic composition of the rock units exposed on the Bahamas islands. (a) Partial flooding, sea-level lower than present: production of bioclasts by bank-margin reefs, deposition of bioclastic rock-bodies (stage 7, substage 5a). (b) Moderate flooding, sea-level stand like present: ooids may be produced locally, but the bulk of material brought to islands is made of bioclastic fragments (stage 1). (c) Complete flooding, sea level higher than present: increased production of ooids due to active water circulation on the platform, deposition of ooliticpel oidal units (stage 9 , substage $5 e$ ).

sea-level changes controlling the petrography of the stratigraphic units must have been induced by eustatic phenomena. The frequency of these fluctuations $\left(10^{4}-10^{5} \mathrm{yr}\right)$ can logically be correlated with orbital cyclicities and hence with climate changes (e.g. Imbrie et al., 1984). Preliminary study of cement textures further shows that climatic conditions during complete flooding of the banks may have been different from those existing during partial flooding. The common occurrence of coarse sparry cement within stage 9 and substage 5e oolites (Fig. 13) suggests a rather humid climate, characterized by small seasonal changes (Ward, 1973). In contrast, the finely crystallized cements (Fig. 9) frequently observed within stage 7 and substage $5 a$ bioclastic calcarenites corresponds to a more arid and seasonal climate (Ward, 1973). However, these assumpti ons cannot be considered as facts until more is known about the relative importance of the primary mineralogy of constituent grains on cement textures.

\section{Correlation with deep-water deposits}

In their study of slope and trough sedimentation in the Bahamas, Haak \& Schlager (1989) and Schlager et al. (1994) proposed a model similar to ours to explain the difference of petrographic composition between turbidites formed during glacial periods, which are dominated by skeletal components, and their interglacial counterparts, which are characterized by ooids and peloids. According to these authors, ooids and peloids are predominant in interglacial turbidites because flooding of the bank tops by a shallow $(<10 \mathrm{~m})$ layer of water is favourable to their production. In contrast, due to bank exposure, these particles rarely occur within turbidites formed during glacial periods, which essentially contain bioclasts produced by lowstand reefs anchored on the platform flanks. Our model is thus consistent with Haak \& Schlager's (1989) and Schlager et al.'s (1994) observations. However, the shoreline deposits studied in this paper were all deposited during periods of relative sea-level highstand. Because of the steepness of the platform slopes, skeletal dunes could not accumulate on the bank margins during a full glacial period, when sea level was roughly $120 \mathrm{~m}$ below modern ordnance datum. Therefore, the observed petrographic variations only reflect small-scale $(10-30 \mathrm{~m})$ sealevel changes during an interglacial period and not the large-scale $(100 \mathrm{~m})$ glacial-interglacial fluctuations recorded by basinal turbidites. According to Schlager et al. (1994), such small sea-level variations are sufficient to shift the 'carbonate factory' on a rimmed platform from a highstand mode (ooid and peloid production) to a lowstand mode (bioclast production).

\section{CONCLUSIONS}

Our multi-method approach to Bahamian Quaternary geology now provides a refined stratigraphic record for this region based on observations from several islands. This record includes eight fossil 
shoreline units, two of Holocene age and six of Pleistocene age. Three units (I, IV and V) were formed when sea level was higher than today. They predominantly consist of ooids and peloids bound by coarse sparry cement. Four units (II, III, VI and VIII) were deposited at or below modern sea-level ordnance datum. These rock bodies essentially contain bioclastic particles and usually display finely crystallized spar cement. The middle Hol ocene ool ite (VII) was also formed when sea level was lower than today, but it represents an early transgressive event which is not representative of stage 1 sedimentation.

We propose that climate and sea-level changes during the Quaternary directly controlled the petrographic composition of the stratigraphic units exposed on the Bahamas islands. During isotope stage 9 and substage 5e, complete flooding of the platform, possibly related to warm and humid climatic phases, resulted in increased production and accumulation of ooids and peloids; in contrast, during periods of partial or moderate platform flooding (stage 7, substage $5 a$ and stage 1 ), which could correspond to dryer climatic phases, sedimentation was dominated by bioclastic components produced by marginal reefs.

Our study shows that petrographic analysis is a val uable complementary tool for correl ating lithostratigraphic units within and between Bahamian islands. It further suggests that petrographic composition and cementation patterns from ancient coastal carbonates could also provide useful information on past climate and sea-level changes.

\section{ACKNOWLEDGMENTS}

This work was supported by grants from the National Science Fund of Switzerland (project 20-29917.90 and 20-40638.94). For logistical support, we are very grateful to R.I. Wicklund and G. Wenz (Caribbean Marine Research Centre, Lee Stocking Island), to D.T. and K. Gerace (Bahamian Field Station, San Salvador), to U. Hinrichsen (Greenwood Inn, Cat), to the Cambridge Family (Gregory Town, Eleuthera) and to J.A. Brown (Bimini). Special thanks to J. Metzger for his help in drafting the figures. Reviews of an earlier daft by A.C. Hine and E. Purdy greatly improved the final version of this paper.

\section{REFERENCES}

A urell, M., McNeill, D.F., Guyomard, T. and Kindler, P. (1995) Pleistocene shallowing-upward sequences in New Providence, Bahamas: signature of highfrequency sea-level fluctuations in shall ow carbonate platforms. J. sedim. Res., B65, 170-182.

Bain, R.J. and Kindler, P. (1994) Irregular fenestrae in Bahamian eolianites: a rainstorm induced origin. J. sedim. Res., A 64, 140-146.

Ball, M.M. (1967) Carbonate sand bodies of Florida and the Bahamas. J. sedim. Petrol., 37, 556-591.

Bathurst, R.B.G. (1975) Carbonate Sedimentology and Diagenesis. Elsevier, Amsterdam.

Beach, D.K. and Ginsburg, R.N. (1980) Facies succession of Pliocene-Pleistocene carbonates, Northwestern Great Bahama Bank. Bull. Am. Ass. petrol. Geol., 64, 1634-1642.

Caputo, M.V. (1993) Eolian structures and textures in oolitic-skeletal calcarenites from the Quaternary of San Salvador Island, Bahamas: a new perspective on eolian limestones. In: Mississippian Oolites and Modern Analogs (Ed. by B. D. Keith and C. W. Zuppann), Am. Ass. petrol. Geol. stud. geol., 35, 243-259.

Carew, J.L. and Mylroie, J.E. (1985) The Pleistocene and Holocene stratigraphy of San Salvador Island, Bahamas, with reference to marine and terrestrial lithofacies at French Bay. In: Pleistocene and Holocene Carbonate Environments on San Salvador Island, Bahamas (Ed. by H. A. Curran), pp. 11-61. Geol. Soc. Amer. annu. Meet. Guidebook, CCFL, Bahamian Field Station, Fort Lauderdale, FL.

Carew, J.L. and Mylroie, J.E. (1987) A refined chronology for San Salvador Island, Bahamas. In: Proceedings of the Third Symposium on the Geology of the Bahamas (Ed. by H. A. Curran), pp. 35-44. CCFL, Bahamian Field Station, Fort Lauderdale, FL.

Carew, J.L. and Mylroie, J.E. (1991) A stratigraphic and depositional model for the Bahama Islands. Geol. Soc. Am. Abstr. with Programs, 23/1, 14.

Chayes, F. (1956) Petrographic Modal Analysis. Wiley, New York.

Chen, J.H., Curran, H.A., White, B. and Wasserburg, G.J. (1991) Precise chronology of the last interglacial period: ${ }^{234} U-{ }^{230} \mathrm{Th}$ data from fossil coral reefs in the Bahamas. Bull. Am. Ass. petrol. Geol., 103, 82-97.

Demicco, R.V. and Hardie, L.A. (1994) Sedimentary structures and early diagenetic features of shallow marine carbonate deposits. Soc. econ. Paleont. Miner Atlas serie, 1.

Eberli, G.P. and Ginsburg, R.N. (1989) Cenozoic progradation of Northwestern Great Bahama Bank, a record of Iateral platform growth and sea-level fluctuations. In: Controls on Carbonate Platform and Basin Development (Ed. by P. D. Crevello, J. L. Wilson, J. F. Sarg and J. F. Read), Spec. Publ. Soc. econ. Paleont. Miner., 44, 339-351.

Flügel, E. (1982) Microfacies Analysis of Limestones. Springer-Verlag, Berlin.

Friedman, G.M. (1959) Identification of carbonate minerals by staining methods. J. sedim. Petrol., 29, 87-97.

Friedman, G.M. (1964) Early diagenesis and lithification in carbonate sediments J. sedim. Petrol., 34, 777-813. 
Gardner, R.A.M. and McLaren, S.J. (1993) Progressive vadose diagenesis in late Quaternary aeolianite deposits? In: The Dynamics and Environmental Context of Aeolian Sedimentary Systems (Ed. by K. Pye), Spec. Publ. geol. Soc., 72, 219-234.

Garrett, P. and Gould, S.J. (1984) Geology of New Providence Island, Bahamas. Bull. Am. Ass. petrol. Geol., 95, 209-220.

Gavish, E. and Friedman, G.M. (1969) Progressive diagenesis in Quaternary to Late Tertiary carbonate sediments: sequence and time scale. J. sedim. Petrol., 39, 980-1006.

Gerhardt, D.J. (1983) The anatomy and history of a Pleistocene strand plain deposit, Grand Bahama Island, Bahamas. MS thesis, University of Miami.

Gifford, G.A. (1973) A description of the geology of the Bimini Islands, Bahamas. MS thesis, University of Miami.

Haak, A.B. and Schlager, W. (1989) Compositional variations in calciturbidites due to sea-level fluctuations, late Quaternary, Bahamas. Geol. Rdsch., 78, 477-486.

Halley, R.B. (1978) Estimating pore and cement volumes in thin section. J. sedim. Petrol., 49, 969-988.

Harrel, J. (1981) Measurement errors in the thin-section analysis of grain packing. J. sedim. Petrol., 51, 674676.

Harris, P.M. (1979) Facies anatomy and diagenesis of a Bahamian ooid shoal. Sedimenta VII, University of Miami.

Hearty, P.J. and Kindler, P. (1993a) New perspectives on Bahamian geology: San Salvador Island, Bahamas. J. coast. Res., 9, 577-594.

Hearty, P.J. and Kindler, P. (1993b) An illustrated stratigraphy of the Bahama Islands: in search of a common origin. Bahamas J. Sci., 1, 28-45.

Hearty, P.J. and Kindler, P. (1994) Straw men, glass houses, apples and oranges: a response to Carew and Mylroie's comment on Hearty and Kindler (1993). J. coast. Res., 10, 1095-1104.

Hearty, P.J. and Kindler, P. (1995) Sea-level highstand chronology from stable carbonate platforms (Bermuda) and The Bahamas. J. coast. Res., 11, 675-689.

Hearty, P.J., Miller, G.H., Stearns, C.E. and Szabo, B.J. (1986) Aminostratigraphy of Quaternary shorelines in the Mediterranean basin. Bull. geol. Soc. Am., 97, 850-858.

Hearty, P.J., Vacher, H.L. and Mitterer, R.M. (1992) Aminostratigraphy and ages of Pleistocene limestones of Bermuda. Bull. geol. Soc. Am., 104, 471480.

Hine, A.C. (1977) Lily Bank, Bahamas: history of an active oolite sand shoal. J. sedim. Petrol., 47, 15541581.

Hine, A.C., Wilber, R.J. and Neumann, A.C. (1981) Carbonate sand bodies along contrasting shallow bank margins facing open seaways in Northern Bahamas. Bull. Am. Ass. petrol. Geol., 65, 261-290.

Hutto, T. and Carew, J.L. (1984) Petrology of eolian cal carenites, San Sal vador, Bahamas. In: Proceedings of the Second Symposium on the Geology of the
Bahamas (Ed. by J. W. Teeter), pp. 197-207. CCFL, Bahamian Field Station, Fort Lauderdale, FL.

Illing, L.V. (1954) Bahamian calcareous sands. Bull. Am. Ass. petrol. Geol., 38, 1-95.

Imbrie, J., Hays, J.D., Martinson, D.G., Mclntyre, A., Mix, A.C., Morley, J.J., Pisias, N.G., Prell, W.L. and Shackleton, N.J. (1984) The orbital theory of Pleistocene climate: support from a revised chronology of the marine $\delta^{18} \mathrm{O}$ record. In: Milankovitch and Climate, Part I (Ed. by A. L. Berger et al.), pp. 269305. Reidel Publishing Company, Dordrecht.

Itzhaki, Y. (1961) Contribution to the study of the Pleistocene in the coastal plain of Israel. Bull. Isr. geol. Surv., 32, 1-9.

Kindler, P. (1992) Coastal response to the Holocene transgression in the Bahamas: episodic sedimentation vs. continuous sea-level rise. Sediment. Geol., 80, 319-329.

Kindler, P. (1995) New data on the Holocene stratigraphy of Lee Stocking Island (Bahamas) and its relation to sea-level history. In: Terrestrial and Shallow Marine Geology of the Bahamas and Bermuda (Ed. by H. A. Curran and B. White), Spec. Pap. geol. Soc. Am., 300, 105-116.

Kindler, P. and Bain, R.J. (1993) Submerged Upper Holocene beachrock on San Salvador Island, Bahamas: implications for recent sea-level history. Geol. Rdsch., 82, 241-247.

Kindler, P. and Hearty, P.J. (1995) Pre-Sangamonian eolianites in the Bahamas? New evidence from Eleuthera Island. Mar. Geol., 127, 73-86.

Land, L.S., MacKenzie, F.T. and Gould, S.J. (1967) Pleistocene history of Bermuda. Bull. geol. Soc. Am., 78, 993-1006.

Longman, M.V. (1980) Carbonate diagenetic textures from nearsurface diagenetic environments. Bull. Am. Ass. petrol. Geol., 64, 461-487.

Lynts, G.W. (1970) Conceptual model of the Bahamian Platform for the last 135 million years: Nature, 225, 1226- 1228.

McLaren, S.J. (1993) Use of cement types in the palaeoenvironmental interpretation of coastal aeolianite sequences. In: The Dynamics and Environmental Context of Aeolian Sedimentary Systems (Ed. by K. Pye), Spec. Publ. geol. Soc., 72, 235-244.

Miller, G.H. and Brigham-Grette, J. (1989) A mino acid geochronol ogy: resolution and precision in carbonate fossils. Quat. Int., 1, 111-128.

Miller, J. (1988) Microscopical techniques: 1. Slices, slides, stains and peels. In: Techniques in Sedimentology (Ed. by M. Tucker), pp. 86-107. Blackwell Scientific Publications, London.

Mullins, H.T. and Lynts, G.W. (1977) Origin of the northwestern Bahama Platform: review and reinterpretation. Bull. geol. Soc. Am., 88, 1447-1461.

Newell, N.D., Purdy, E.G. and Imbrie, J. (1960) Bahamian oolitic sand. J. Geol., 68, 481-497.

Newell, N.D. and Rigby, J.K. (1957) Geological studies on the Great Bahama Bank. In: Regional Aspects of Carbonate Deposition (Ed. by R. J. Le Blanc and J. G. Breeding), Spec. Publ. Soc. econ. Paleont. Miner., 5, 15-72. 
Pierson, B.J. and Shinn, E.A. (1985) Cement distribution and carbonate mineral stabilization in Pleistocene limestones of Hogsty Reef, Bahamas. In: Carbonate Cements (Ed. by N. Schneidermann and P. M. Harris), Spec. Publ. Soc. econ. Paleont. Miner., 36, 153-168.

Purdy, E.G. (1963) Recent calcium carbonate facies of the Great Bahama Bank. J. Geol., 71, 472-497.

Richter, D.K. (1983) Calcareous ooids: a synopsis. In: Coated Grains (Ed. by T. M. Peryt), pp. 71-99. Springer Verlag, Berlin.

Robinson, R.B. (1967) Diagenesis and porosity development in recent and Pleistocene ool ites from Southern Florida and the Bahamas. J. sedim. Petrol., 37, 355364.

Schlager, W., Reijmer, J.J.G. and Droxler, A. (1994) Highstand shedding of carbonate platforms. J. sedim. Res., B64, 270-281.

Simone, L. (1981) Ooids: a review. Earth-Sci. Rev., 16, 319-355.

Stowers, R.E. II, Carew, J.L. and Mylroie, J.E. (1989) Pleistocene stratigraphy and geochronology, southwestern San Salvador Island, Bahamas. In: Proceedings of the Fourth Symposium on the Geology of the Bahamas (Ed. by J. E. Mylroie), pp. 323-330. CCFL, Bahamian Field Station, Fort Lauderdale, FL.

Strasser, A. and Davaud, E. (1986) Formation of Holocene limestone sequences by progradation, cementation, and erosion: two examples from the Bahamas. J. sedim. Petrol., 56, 422-428.

Vacher, H.L. (1973) Coastal dunes of younger Bermuda. In: Coastal Geomorphology (Ed. by D. R. Coates), pp. 355-391. State University of New York, New York.
Vacher, H.L. and Hearty, P.J. (1989) History of Stage 5 sea level in Bermuda: Review with new evidence of a rise to present sea level during Substage 5a. Quat. Sci. Rev., 8, 159-168.

Voss, G.L. (1988) Coral Reefs of Florida, Pineapple Press, Sarasota.

Ward, W.C. (1973) Influence of climate on the early diagenesis of carbonate eolianites. Geology, 1, 171174.

Ward, W.C. (1975) Petrology and diagenesis of carbonate eolianites of Northeastern Yucatan Peninsula, Mexico. In: Carbonate Sediments, Clastic Sediments, and Ecology (Ed. by K. F. Wantland and W. C. Pusey), Am. Ass. petrol. Geol. stud. geol., 2, 500-571.

Wehmiller, J.F. (1983) A review of amino acid racemization studies in Quaternary molluscs: stratigraphic and chronologic applications in coastal and interglacial sites, Pacific and Atlantic coasts, United States, United Kingdom, Baffin Island and tropical islands. Quat. Sci. Rev., 1, 83-120.

White, B. and Curran, H.A. (1988) Mesoscale physical sedimentary structures and trace fossils in Holocene carbonate eolianites from San Salvador Island, Bahamas. Sediment. Geol., 55, 163- 184.

Wilber, R.J. (1987) Geology of Little San Salvador and West Plana Cay: preliminary findings with implications for Bahamian stratigraphy. In: Proceedings of the Third Symposium on the Geology of the Bahamas (Ed. by H. A. Curran), pp. 181-204. CCFL, Bahamian Field Station, Fort Lauderdale, FL.

Manuscript received 26 January 1995; revision accepted 19 October 1995. 
